Computers and philosophy. A proof of infinity in the XVII ${ }^{\text {th }}$ century.

Camille Akmut 


\section{PREFACE}

When we think of the origins of computers we think of a handful of philosophers and a "third man"; because history, when conducted properly, always ends up revealing this other person, whoever they are, and the next.

However our understanding of these issues may one day look, it remains that :

If, our computers - these tools that we use, and take for granted - come from them then we must understand their thoughts;

and understand the people who came up with the devices that now fill our lives.

Pascal solved engineering problems before solving philosophical ones:

If this is so : What does it say about us?

There are two Pascals - one sold his Machine, the other 'thought' it;

two attitudes corresponding roughly to his early and later life (the latter period saw the emergence of their major philosophy work);

Between worldly dispositions and contemplative retreat : "hustler", as we put, and uncompromising thinker.

In Pascal we find a strangely modern figure, and uncomfortable mirror.

We recognize in him the traits seen in others; minus the philosophy for some... 
"My dear, dear brother,

I feel as much joy knowing you gay in solitude,

as I was pained when I knew you to be happy in the world."

(Jacqueline Pascal, 1655)

/

"The machine for arithmetics has effects that are closer to thought than anything in animals; but it ["elle"] does nothing that would allow us to say it has will ..."

(Pascal, Pensees) 


\section{PASCAL, THE BOY GENIUS GEOMETRY, SOCIAL GEOMETRY.}

2 OUT OF TIME HEALTH. 


\title{
The young Pascal : bourgeois origins, exceptional education, health.
}

Camille Akmut

May 1, 2020

\begin{abstract}
"Pascal, the boy genius" - geometry, social geometry (i.e. sociology), etc. etc.
\end{abstract}


In Europe, the 17th century was defined by "a clear hierarchy" of social divisions,

"the first consisted of servants of the church, the second of the no-

bility, the third of commoners"1.

The word class inspires such tremendous fears in the mind of the Early modern historian that they almost never use it without quotation marks : this one for instance insists "society was more complex", only to later downplay the usefulness of class as concept to understand this and, it is understood, all other periods of history.

"Trying to make all this fit into a 'class' structure is not very helpful", he opined.

We recognize here the sure signs of the professorial mind at work. ${ }^{2}$

But, the notion that "class" should have somehow skipped, or been exterior to, or otherwise incompatible with the 17th century is comical at best.

Far from universal, such views of history do not make us forget the passages of The Communist Manifesto whose (less naive) philosophy of history starts from the beginning, i.e. Antiquity.

The group (or "estate") of commoners was itself heterogeneous;

\footnotetext{
${ }^{1}$ Munck $2001: 52$.

${ }^{2}$ The "professorial mind", evoked by Bachelard in the beginning pages of The formation of the scientific mind, reflects a certain spiritual quality - dogmatism - that comes among others from repeating the same lectures over and over, he advanced. [Bachelard due to his socio-economic characteristics was best fit to create this, mocking, professorial anthropology.])
} 


\section{I - The Pascal family : bourgeois origins}

Being neither nobles nor Churchmen, the Pascal's were part of this other society that would soon become the whole of society, and belonged to its upper ranks

— the bourgeoisie.

In England, at the same time, the poor constituted half of society ${ }^{3}$ :

e.g. "common seamen and soldiers, labourers, servants, cottagers, paupers, and vagrants"

This, on the other hand, was clearly not the sort of demographic that Pascal joined at the time of his birth.

("The difficulty for the historian lies in being sensitive to changes, but yet not being obsessed by them to the point of forgetting the great forces of inertia" 4 . Or, "whether in Venice or Beauvais", as Braudel liked to put ${ }^{5}$.)

With little reason to expect any significant differences existing within French society : as pertaining to the century and country of Pascal :

"towns soon had to protect themselves against ... regular invasions, which were not purely by beggars from the surrounding areas but by positive armies of the poor (...)

The attitude of the bourgeois hardened considerably towards the end of the sixteenth century, and even more in the seventeenth.

The problem was to place the poor in a position where they could do no harm.

\footnotetext{
${ }^{3}$ Munck 2001 : 66, based on the statistics established by Gregory King ("yearly income of 20 pounds or less"). Critical discussion ibid.

${ }^{4}$ Aries 1975 : 1-2. Contemporary historians triumph in their perception of his mistakes, but could have never come up with his ideas. I.e. death is inevitable $>$ my death $>$ your death? Not if they had a thousand lives!

${ }^{5}$ Author of other such sentences like "A few overfed rich do not alter the rule" (Bless him!)
} 
In Paris the sick ... had always been directed to the hospitals, and the

fit, chained together in pairs, were employed at the hard, exacting and interminable task of cleaning the drains of the town." 6

Etienne, father of our philosopher, was president of one of the so-called 'Court of aids' that existed at the time, institutions overseeing tax matters.

Said philosopher had also an older sister, called Gilberte, who wrote down her memories : Here is how her biography begins :

"Life of Blaise Pascal

by Mrs. Perier, his sister

My brother was born in Clermont, on the 19th of June of the year

1623. [Mon pere ... Etienne Pascal, president en la cour des aides]"

He occupied, to use perhaps anachronistic terms, an executive role (in the State); this was a comfortable position, and in the Pascal household no one had to worry about food, rent...

The state of medicine at the time was such that death was present all around; from which we do not conclude that all were equal in front of it;

Antoinette, nee Begon, mother of the philosopher, died when he was 3 years old $^{7}$. She was 28 years old herself ${ }^{8}$. (Average life expectancy : 30.)

$\sim$ What would have become of Pascal had he been less fortunate? Hyp. 1: clergyman; 2: worker constructing a calculator for someone else; 3: hospital.

\footnotetext{
${ }^{6}$ Braudel 1985 : 75. Many tables ibid.. These developments lead straight to the original work of Michel Foucault.

${ }^{7}$ Gilberte's biography.

${ }^{8}$ Jacqueline Pascal's memoir.
} 


\section{II - An exceptional education}

Etienne Pascal being able to retire from active life because of his fortune :

The importance of these facts cannot be overstated.

Gilberte, in her writings, linked them directly to Pascal's intensive education; now freed from work Etienne could focus on this task.

"In the year 1631, my father retired [i.e. left 'active life' i.e. stopped working] to Paris, where he established his residence. ... my brother benefited tremendously from this; in the Province [where he had previously worked] he would have been unable to educate him with the same care." 9

This is in addition to the subsequent move to Paris with his family, where access to culture and society should have been easier than in the province, where they had previously lived.

Etienne was devoted to his children, this included their education. (A role that otherwise would have been Antoinette's, and was traditionally the domain of women (if homeschooling)?)

This attention was focused in particular on Blaise; a decision based on gender and perceived abilities. This had not escaped his sister Gilberte, who wrote :

"As he had only this one son, and no other; [said fact] combined with the outstanding intellectual qualities he recognized in this child, awakened in him such great love that he could not bring himself to delegate his education to any other, thus took charge of it himself." 10

His son's fame would be such that soon it was understood that under the

\footnotetext{
${ }^{9}$ First page.

${ }^{10}$ Gilberte's biography.
} 
sole denomination "Pascal", and "Mr. Pascal" ${ }^{11}$, only Blaise could be meant.

[We generally write of Pascal in this way.]

\section{III - Education in the 17th c.}

The notion of a child's education's importance,

"is not a case of isolated observations but of a real doctrine - gen-

erally accepted by Jesuits as by Oratorians ${ }^{12}$ or Jansenists - which

partly accounts for the profusion of educational institutions, colleges,

little schools and special establishments ..."13

Let us now try to reconstitute the educational landscape, the education of children especially, during that time.

The biggest event in this century, and country, was no doubt the Royal ordinance of $1698^{14}$ which made schooling compulsory : from then on parents would need to send their children to equivalents of now- primary schools, the so-called "petites ecoles" (or lit. 'small schools').

However, Pascal was born some seventy years ealier, in 1623, and this raises the question of what happened to children before then.

In his famed history of childhood and family Aries gives the example of a 'little prodigy' of the 16th century (H. de Mesmes, lawyer-son-of-a-lawyer, doctor of Law at 18), noting however that :

"Cases of this type were to become rare in the seventeenth cen-

tury, not only because precocity would strike public opinion as an

\footnotetext{
${ }^{11}$ As the Pensees were originally known in full title ("Quelques pensees de M. Pascal sur...")

${ }^{12}$ Oratorians being the likely least well-known of these groups : they were associated with Malebranche, 'the Oratorian philosopher' (just as Pascal, Arnauld et al. represented the Jansenists).

${ }^{13}$ Aries 1962 : 114.

14 (by Louis XIV)
} 
anomaly," 1516

but because of the transition from an education organized in branches, that could be explored rather freely, to "a continues series of classes", whose predefined path should be followed (this remains our dominant conception).

Hence "colleges" (e.g. the College de Bourgogne frequented by de Mesmes) were available as form of education, but constituted a possibility rather than a norm.

Likewise for the "petites ecoles" :

e.g. Racine had attended the ones of Port-Royal, homeschooling being out of the question in his case, having lost both parents. ${ }^{17}$

From Gilberte's biography we know that "this [homeschooling] is everything he [Pascal] had ever learned, n'ayant jamais ete au college", having never attended a "college";

Having also never had any masters other than his father. ${ }^{18}$

Would Pascal have been happy in a school (had he had a say)? We can speculate.

However, we do not need to speculate on the details :

Pascal's sister Jacqueline has herself left us a document in which she was asked to explain the rules used inside her school :

This included regulations of hours, content; and some abuse, possibly ${ }^{19}$.

"On [the topic of] when Children [should] wake up

\footnotetext{
${ }^{15}$ Aries $1962: 195$.

${ }^{16}$ Note that Jacqueline Pascal and Port-Royal are encountered again in this book (see for example pp. $27 ; 114$; etc.).

${ }^{17} \mathrm{He}$ would later go on to write a book about Port-Royal.

${ }^{18}$ G. Perier, p. 6.

${ }^{19}$ Aries has insisted on the disciplinary aspects of these institutions : “... [and] the evolution of school life in the direction of stricter discipline." (Aries 1962: 114.)
} 
1. The oldest get up at four hours [followed by younger children, at the latest at five] and [only] the youngest ones based on their needs and abilities.

As, you must recall, we have here children whose ages range from 4

to 18 .

$(\ldots)$

Following prayers, they go put their beds in order

$(\ldots)$

We make sure they remain modest ... keep straight [etc.]" 20

(She was writing a report to a superior.)

But, in the context of his homeschooling Pascal could strive : however Etienne was no average homeschooler, having good knowledge in the mathematics of his time; in addition to studies in law ${ }^{21}$ (law was a prestigious subject then).

\section{IV - Etienne Pascal, the forgotten mathematician}

"My father was a learned man in the mathematics",

Gilberte wrote ${ }^{22}$.

Mathematician-descending-from-another : Pascal did not escape this sociological rule by which alone large parts of the history of this discipline could be summarized. ${ }^{23}$

"Small time" mathematician who was part of various scientific circles and societies, Etienne has been described like so (during this period of his life) :

\footnotetext{
${ }^{20}$ J. Pascal 1657. Pp. 230-239. (a hundred-some pages report!)

${ }^{21} \mathrm{M}$. Perier, first page.

${ }^{22}$ G. Perier, p. 3.

${ }^{23}$ This should prompt commentators to be more careful when using, and abusing, the word "genius" - in reference to mathematicians at least ("pure", applied alike). It does not suffice to explain their own accomplishments, but at the very least offers a useful context for them, other than vague notions.
} 
He was cozy with ["il frequentait intimement"] a small society of mathematicians, formed around the Pere Mersenne.

There met Roberval, Desargues, Mydorge, Hardy, the abbot Chambon, Le Pailleur, Bouilliaud. Group meetings, which were weekly, mostly happened at Mersenne's home, Hotel des Minimes, sometimes at other people's. (...)

In 1634 he was actively involved in the Morin affair/controversy [who claimed to have made a discovery].

(...) Richelieu calls on 5 inquirers [among which Pascal (the father)...] (...)

It was around 1636 that Fermat initiated contact with the [Mersenne group] $\ldots{ }^{24}$

Beyond this, it is worth noting that Etienne Pascal's skills within mathematics covered geometry, and the construction of triangles ${ }^{25}$; a fact of interest considering Pascal's lasting interest in this subject.


\section{ESSAY.POVR LES CONIQVES. Par B. P.}

Figure 1: Pascal's early paper

\footnotetext{
${ }^{24}$ (cf. Brunschvicg/Boutroux 1923 : 169-ff)

${ }^{25}$ Ibid.
} 
(Gilberte describes him as playing with various forms of triangles and their properties, as child.)

At the very end of his Essay on cones - what can be considered his first major mathematical work - Pascal, then still quite young, made this modest and memorable statement :

"We have many more theorems and conclusions; but having so little experience, as we do, we would prefer to wait and would like that more knowledgeable/experienced ["adroit"] people first go through our writing : after this, and if it is judged worthy to be resumed, we will, and pursue it as far as God will give us the strength to."

He was 16 (or 17) :

"Winter of 1639-1640" according to Brunschvicg/Boutroux 1923 : 245, based on G. Perier. Taton gives "nov. ?" 1639 for elaboration and "feb. ?" 1640 for publication dates (Taton 1962). 
-When you're in that kind of pain, it's hard to take the world for granted.-

\section{I - Pascal's changing health}

The most important testimony on the general development of Pascal's health comes arguably from his sister Gilberte,

"sa sante ... commenca d'etre alteree des qu'il eut atteint l'age de

dix-huit ans." 26

who places (major) changes in his health intervening during his 18th year.

From Marguerite Perier, Pascal's niece, this episode in the early life of the philosopher is also known :

"at mid-day, coming back from the palace, my grandfather [Etienne]

saw the entire household in tears: the child [Pascal] seemed to be

lying dead in his cradle."

It gives us another opportunity to consider medicine during this time, and especially attitudes towards it.

Etienne, this learned man became convinced that his child had been put under a spell (though having first rejected $\mathrm{it}^{27}$ );

Because the issues with the infant Pascal persisted ("eleven to twelve months"28), he resorted to para-medical treatments :

a spell-transfer and "a mixture of nine leaves from three different

herbs collected by a child of seven years picked before sun-up" ${ }^{29}$

${ }^{26}$ P. 6.

${ }^{27}$ M. Perier.

${ }^{28}$ Strowski $1907: 4$.

${ }^{29}$ Strowski $1907: 4$. 
Beyond this, however, there were no more difficulties : "the child was healed"!

We see no coincidence in the fact that Pascal's so-called "first conversion" coincides more or less with the worsening of his health state :

The chronological table of Pascal's life and scientific activities established by Rene Taton gives January-April 1946, and 1647 (without further indication) respectively. ${ }^{30}$

From this we conclude it is around the ages of 18 23-24

observed and that we should see a major (lasting) change happening in Pascal where the topic of (his) health is concerned.

\section{II - 17th c. medicine}

Austria, a leading clinic in 1842 (Cousin gives his report) : " $27 \%$ of women giving birth died in August, 29[20]\% in October of that same year, and 33 deaths were counted for every 100 childbirths on average in December..."

I.e. women giving birth here had roughly 1 chance in 3 to die.

The idea that washing hands before medical procedures should help stop the spread of diseases was received as if the most absurd thing in the world. Yet, going from dissecting cadavers to helping in childbirth was normal (e.g. a part of students' learning).

Such was medicine even into the 19th century.

This was no backwater practice either but the General Hospital of Vienna. The unit lead by the Prof. Dr. Klein (who opposed Semmelweis) ${ }^{3132}$.

\footnotetext{
${ }^{30}$ Taton 1962.

${ }^{31}$ Celine keeps calling him 'Klin', describes him as a man "full of assurances and strictly mediocre", and plainly an imbecile... ("Semmelweis never loved Vienna")

${ }^{32}$ Today, in that same hospital, a doctor is in charge of deciding over the fate of transgender
} 
And, now we can imagine a society 200 years before those events - the society in which Pascal and his contemporaries lived; before the facts.$$
* * *
$$

If the state of hygiene was such as described in the century of Semmelweis (lacking even minimal understanding in medical professionals, and worse much resistance against attempts at reform), the one of the 17th can be expected to be equal or worse :

Celine makes this observation about previous attempts :

"Many other commissions had fallen apart trying to solve this ageold problem. But, among them, the least useless ["inefficace"] was perhaps that instituted by Louis XVI during the puerperal* epidemic of 1774 which ravaged the Hotel-Dieu hospital in Paris"
\end{abstract}

$\left[{ }^{*}\right.$ We make this annotation : infections occurring in women during childbirth.]

To understand the catastrophic ${ }^{33}$ state of medicine in the 17th century we can start by acknowledging that it was not uncommon for doctors to resort to supernatural explanations as part of their thinking or practices : and sometimes even extraterrestrial ones, as in this case :

"Many medical professors, influenced by the sixteenth-century Paris physician, Jean Fernel (1485-1558), even argued that many qualities, especially those present in the body's fluids when an individual fell victim to a major disease like the plague, were unknowable and occult, the result of planetary influences." 34

people : K., gynecologist, (thus) direct descendant of the "dumb" Johann Klein.

${ }^{33}$ In the same way that observers in some centuries from now may note the basic state of our own medicine, remarking for instance that we were unable to find vaccines for diseases "as simple as flus"; these judgments of values are relative : yet there is a big step from astrology-medicine to current epidemiology.

${ }^{34}$ Brockliss 2001 : 150 . 
This was the nec plus ultra, the best of knowledge assembled by some of these professors : A medicine not too far from astrology.

Influenced primarily by (their readings of) the philosophies of St. Augustine and what one could call a "Christianized" Aristotele.

It is worth noting here that Cornelius Jansen, of Jansenism, (the current with which Pascal identified), is the author of a study on St. Augustinus including his thoughts on health and medicine $[\text { de ... sanitate, aegritudine, medicina .... }]^{35}$.

Some doctors were brilliant in some areas, and in others failed. Like the royal physician William Harvey ${ }^{36}$ :

Having described blood circulation, he also linked it with the soul, and, in other matters, viewed semen as so powerful it could fertilize "at a distance", "without physical contact"...37

One interesting take on medicine during this time were conceptions of the body as machine :

Galilei and Gassendi ${ }^{38}$ (who offered an interpretation for Pascal's barometer experiments) "tought about the body in mechanical terms: ... in Galileo's terms, an assemblage of small machines. (...) [They] studied the physical principles of ... how the pores secreted, how ... the stomach digested, [and] blood flowed ..."39

If medicine was powerless, any injury, or illness, could quickly mean death.

\footnotetext{
${ }^{35}$ On Augustine: "His library included clinical textbooks and, while composing his replies to Julian of Eclanum, he studied the best guide to gynaecology." (Chadwick 2001 : 121). ${ }^{36}(1578-1657)$.

${ }^{37}$ Summed up from Wiesner-Hanks $2013: 295$.

38 (1592-1655). French.

${ }^{39}$ Wiesner-Hanks 2013 : 296.
} 
For the period leading up to the times of Pascal, Early modern historians offer these indications : e.g. :

"half of children died before they were ten" 40

To give an example close to Pascal, we can cite the case of the Arnauld family - "Antoine Arnauld ${ }^{41}$ and Catherine Marion had twenty children, of whom ten survived." 42

From opposite perspectives, Racine was a famous orphan (of this century).

"Average life expectancy was shockingly low by modern (Western)

standards: barely thirty in the seventeenth century." 43

In Marseille, plague killed half of the population in $1720^{44}$.

Wilhelm Schickard himself died of the plague.

Pascal's own sister, Jacqueline, had her own ideas about medicine too : according to her there was a direct link between spirituality / health :

"I have first felt how health is more dependent on Jesus Christ than Hippocrates, and how the (proper) government ["regime"] of one's spirit heals the body, in so far as God wishes to test us and fortify us through our infirmities." ${ }^{45}$

\footnotetext{
${ }^{40}$ Wiesner-Hanks $2013: 59$.

${ }^{41}$ (1560-1619). Father of Jacqueline ("Mother Angelique") and (the other!) Antoine Arnauld with whom Pascal had an association. (This Arnauld was a bachelor?)

${ }^{42}$ Encyclopedia of the Early modern World, vol. 1.

${ }^{43}$ Encyclopedia of the Early modern... Vol. 2.

${ }^{44}$ Encyclopedia of the Early modern 2.

${ }^{45}$ Letter from 19th of Jan. 1655. P. 555.
} 
3

THERE WAS A HUSTLER

COMMERCIAL - LEGAL ASPECTS

OF A NEW MACHINE. 


\title{
From selling to 'thinking' the Machine: Pascal's intellectual trajectory, sociological aspects.
}

Camille Akmut

May 1, 2020

\begin{abstract}
Information on marketing, networking, patenting, and reflecting the famous machine for arithmetic ('Pascaline'). - "There was a hustler in Pascal"; There was also a philosopher, writer of the Pensees.
\end{abstract}


Sociological aspects of the Pascaline can be found, past its inception, in the steps that follow (such inventions) which are patenting, marketing and selling.

Seller and thinker. Both are reconstituted here. And, some of the steps in the trajectory leading from one to the other...

\section{I - Self-selling and marketing the Pascaline}

"Reader my friend [Dear reader],

by this notice [ad] you will know that I have created a small machine of my own invention, that I should now introduce to the public.

With it only you will be able to perform all the operations of arithmetic, without strain;

and thus will be able to rid / free yourself from the hard work weighing on your mind. (...)

I can, without being presumptuous, hope that it will be pleasing to уои..."

And, so the Pascaline was introduced to the world.

Pascal was plainly selling his Machine. He goes on, preemptively dealing with criticism, and potential competition possibly :

"Some (lesser) scientists will tell you [the Machine could have been better], but believe me when I say that [it is otherwise], and I will show them whenever it suits them, many other models [etc.]"

Of this period, the commentator Michaut tells us : "his ardent [pursuit of] science was still driven by his love of glory"... ${ }^{1}$

\footnotetext{
${ }^{1}$ Michaut 1902: 31 .
} 


\section{II - Networking the Machine, Pascal and social capital}

One of the truly odd episodes in the life of this philosopher :

Pascal had apparently recruited a professor at the College de France - a tremendously prestigious institution - for what must be called objectively marketing purposes.

To the prospective buyer the young man wrote : go see Professor such-andsuch, and he'll give you a free demonstration! Here is his address.

"Those ... who would like to see [such a] the Machine will please contact the sieur Robertval, professor of mathematics at the College [Royal] de France, who will show them - succinctly and free of costs - the ease with which operations can be performed, will sell it to them, and teach them how to use it.

Said Robertval resides ... on Foing street, close to $<$ such and such $>$.

He can be found [there] every morning from < such and such $>$, and on Saturdays the entire afternoon"!

So ended ${ }^{2}$ the Notice describing the Pascaline.

Being reminded at this point of 17 th c. equivalent of Tupperware parties cannot be faulted...

But, there was neither fate here, nor luck, nor a meeting of pure spirits; There was something that mathematicians or computer scientists usually do not like to have surmised of them : social conditions.

The son had used his family's connections, plainly.

The same Roberval ${ }^{3}$ had been a collaborator of his father :

\footnotetext{
${ }^{2}$ In bold, in our copy.

${ }^{3}$ Gilles de Roberval (1602-1675), who appears as "Robertval" in various documents.
} 
Pascal's father was also - this is probably not stressed enough - a "smalltime" mathematician himself, author of one paper that is known to us :

To Fermat from 1636 co-written with the aforementioned distinguished maths prof.. (A lenghty letter.)

These are no doubt the less glorious aspects of the history of science.

Not everyone is quite equal, here either.

The illuminated manuscript (i.e. books with illustrations of religious scenes) had become less common in the century of Pascal : but, these were the "very small hours' of Pascal, and those of the early history of computing and by extension computer science... ${ }^{4}$

Rene Taton, this "fairly pro-Pascalian" historian, reported these events in his article on the invention of the mechanical calculator ${ }^{5}$, but not without some disappointment or a pinch of the heart, it feels ("curious choice...").

\section{III - Easy and 'hard' problems}

Pascal solved engineering problems before solving philosophical ones.

The first ones were the easy ones.

In her biography, Gilberte took note of the following

"This work [the Pascaline] had been very strainous for him, not intellectually or in terms of its implementation, which was quick, but to make all of these various matters clear to the workers."

These events go against contemporary notions of easy and 'hard' problems, associated respectively with the 'soft' and the so-called 'hard' sciences.

\footnotetext{
${ }^{4}$ A play on Grandes Heures and Belles heures, two famous examples of such manuscripts.

${ }^{5}$ Taton 1963, esp. 147.
} 
An important technology entrepreneur not too long ago had the hubris of writing a blog post detailing such views :

(Their case, being one of many, only matters so far as representative of certain moods existing within computer science and technology circles - though certainly not only them.)

The humanities were fads... Or, subject to too many of them to be worthy of study. [From which a reasonable person may deduce they solve complicated problems; as Descartes, this other philosopher-mathematician, implied.]

He did not recommend them in any case, and opined in his wisdom that various other sciences, among them computer science, were better choices.

This gentleman however made one notable exception : the history of science!;

The same now gives us the example of someone, Pascal, who clearly did not conceive of philosophical vs. technical or even technological problems in such terms.

"There are two kinds of minds :

the geometrical one, and the beautiful [keen] one

The first moves forward slowly, harsh and uncompromising

but the latter has a flexibility such that

they may move around all of their favorite subjects

And, yet when both are combined how sweet love becomes!"

From 'Discourse on the passions of Love' (a similar thought is found in the Pensees).

Pascal would soon leave behind the 'easy' problems of his youth, and would thereafter turn to the (real) "hard" ones; we use the latter terminology in the same fashion, still, as some say "hard science". But, to mean philosophy, and the humanities and, anachronistically, the social sciences. 
This former mathematician and engineer would now concentrate his energies on the most difficult problems only; constitutive of the Pensees.

\section{IV - The 1649 patent}

May of 1649 :

Pascal receives a patent (called a "privilege") for his Machine :

"LOUIS, by the grace of God, king of France and of Navarre...

Our dearest and much-loved the sieur Pascal ${ }^{6}$ has shown us that - just like his father le sieur Pascal ${ }^{7}$, [our servent of the State] he had particular aptitudes for the mathematical sciences, in which, through his studies and observations, has invented multiple things, and in particular a machine, by which ... additions, subtractions, multiplications and divisions, and any other rule of arithmetic can be performed [and better, and easier than means of calculation available so far] ... in addition to being free of errors"

Here again, Pascal's father's status and connections and reputation plays a role in the trajectory of the philosopher (for better and worse, depending on fluctuations).

\section{V - What money can buy... Capital in the 17th century}

Circa 1630/1631 :

Etienne Pascal sells his position, at the Court of aids, - as was possible in the day $^{8}-$ and essentially starts living the life of a rentier capitalist (i.e. someone possessing a capital, sum of money / money-equivalents, such that big enough they receive an income from which they live);

\footnotetext{
${ }^{6}$ Blaise is meant.

${ }^{7}$ Etienne.

${ }^{8}$ For this aspect of 17 th c. life, see e.g. Munck 2001.
} 
"vendit sa charge de deuxieme president a la cour des aides a son frere ... et la plus grande partie de ses biens, qu'il mit en rente sur l'hotel de ville de Paris" (as Marguerite reported in her memoirs) ${ }^{9}$

The Pascal family moves to Paris, and enjoys a leisurely life.

Let us say at least some things about what money could buy during this century (and nothing of the international passports and citizenships than can be considered their modern-day equivalents) :

"Especially in western and central Europe, money could provide access to all the trappings of elite status, including noble titles, landed estates, fiscal privileges, coats of arms, seigneurial rights (such as hunting rights, powers of justice and punishment, entitlement to labor services from tenants)" 10

This was in fact how Etienne - Father of Pascal - had made some of his money, fortune :

But, the son would not follow in his father's footsteps however.

A turn attributable to his growing health issues, (it's hard to take the world for granted when you're in that kind of pain), and what we advance to be a sense of delusion with the World, and materialistic pursuits, following the various commercial and legal experiences surrounding the invention of his Machine.

\section{VI - A crisis of conscience}

1654. Pascal has his famous "vision": it had made such an impression on him that he wrote it down and carried the note with him henceforth, sewn into his jacket.

\footnotetext{
${ }^{9}$ P. 419.

${ }^{10}$ Munck 2001 : 54.
} 


\begin{abstract}
"God ... not of philosophers ... Denial of the world ... I have separated myself ... Jesus Christ I have renounced, crucified, ... but so long as not forever. ... Total renunciation ... Total submission to Jesus Christ and my Director" [i.e. one giving directions]
\end{abstract}

The so-called "amulet" : a term coined by Condorcet to refer to the dream note that Pascal carried with himself. (A rather pejorative one considering the notions of magic or witchcraft attached to it.)

[The term "memorial", adopted by others, is more neutral.]

1655. Pascal leaves for Port Royal. ${ }^{11}$

A prince amongst his kind, (having received visits by the likes of Descartes in his teens still), he abandoned them; but with mathematics he also abandoned most his social status.

Deep religious beliefs and convictions, or a fanatic, Pascal?

To put this event into context, we may remind of several analogous ones in the history of sciences :

That a mathematician like Dedekind, for instance, evoked a "voice unknown and mysterious" speaking to him... That Cavailles felt his work, (his thesis specifically), had "a life of its own"... That Wittgenstein kept journals on masturbating $^{12}$, in which he expressed anxieties about purity ${ }^{13} \ldots$

[As for 21st c. computer scientists, they give so much of themselves away that it would too long to list all of their extraordinary ways.]

\footnotetext{
${ }^{11}$ Strowski $1908: 1$.

${ }^{12} \mathrm{Cf}$. Monk's biography.

${ }^{13}$ Interestingly, and perhaps not surprisingly, we gather further about Wittgenstein : "[Augustine's] writings were among the favorite books of Wittgenstein." (Chadwick 2001 : 4). (NB. Augustine, who talked a lot about $\operatorname{sex}($ uality)...)
} 


\section{VII - "The second Pascal" / Butterfly Pascal}

Even Cousin - critical both of the contemporaneous state of the Pensees and some of Pascal's legacy - found Pascal's "love of poverty", an expression he used, touching ${ }^{14}$.

The second Pascal was meant.

Hazard, a man of letters, similarly remembered Pascal as "the [one] man who had most intensively felt the tragic nature of existence" ${ }^{15}$.

There was not as much tragic in Pascal as human :

As he proposed himself, there was no reason to consider philosophers as something else, than human :

Plato and Aristotle laughed like everyone else; it was their lives that were their greatest philosophy (Pensees 331 B) :

"We only imagine Plato and Aristotle as pedants/pedagogues in robes.

These were honest people [folks] who, like everyone else, laughed [in company] of their friends; and when they turned to [writing] their 'Laws' and 'Politics', they did it in that same [playful] spirit; it was the least philosophical and serious part of their lives; the most philosophical was to live simply and peacefully."

And, it was only this Pascal who could have written about the shameful "I"

"The Self is detestable etc. etc." (trans. 1) /

"The [word] 'me' is detestable etc. etc." (trans. 2)

A passage of the Pensees quoted in the Logic of Port-Royal together with the following recollections about Pascal (with whom the author were close, they did live after all in the same place) :

${ }^{14}$ Cousin 1842 : 46 ("touching", was Gilberte's testimony on this topic

${ }^{15}$ Crisis of European... Ch. 5, part 3. (in this study originally published in 1935) 
"Pascal, who knew as much real rhetoric as anyone ever knew, ...

held that an honest man should not name themselves or even make use of the words "I" ("je") and "me" ("moi")."16

In his religion, Pascal found a fitting anthropology which is to say view of of human kind : Pensees 606 B :

"No other religion than ours [implied Christianity] has taught that

Man is born in sin, no philosophy school ["secte"] has claimed it:

thus none was true."

\section{VIII - Thinking the Machine}

'Thinking' the Pascaline followed selling the Pascaline; just as the retired ${ }^{17}$ Pascal followed the worldly one; and, Port-Royal Paris...

In fragment $340 \mathrm{~B}$, the Machine of Pascal makes an appearance :

"The machine for arithmetic has effects that are closer to thought than anything done by animals ; but it ["elle"] does nothing that resembles will, as [present] in animals."

No more marketing. No more promises of "ease of use" (as in the ad, written by a younger Pascal). No more Roberval.

Here Pascal develops thoughts on almost-thinking machines, though yet devoid of own will. A 17th c. thinker!

It's useful to place this fragment together with the surrounding ones (if thematically only) :

\footnotetext{
${ }^{16}$ In the old and new editions we have accessed, this passage is in chapter XX, VI. (In his Report, Cousin places this passage in "IIIrd part, ch. XIX" (Cousin 1842: 45).)

${ }^{17}$ We use retired rather than solitary, as Pascal did have the company of the other believersintellectuals at Port-Royal.
} 
Fragment 339 B : Where do pleasures come from? The body (our hands, for instance)?

Answer : they must be immaterial.

When taken together these thoughts should make pleasures in machines possible; as, again, "il faut que ce soit quelque chose d'immateriel" i.e. the pleasures that are inside of us come from a non-material source.

Its goes even further :

"a Man without hands, feet, and [even] head (for experience tells us a head is more important than [the rest])" I can conceive, continues Pascal, "But, a Man without thoughts I can't".

Directly followed by the passages on machines being - we can conclude somewhere in-between animals and humans; and perhaps one day more. 


\section{Conclusion}

Legal and commercial experiences, the education that adulthood brings sooner or later to everyone, exacerbated health problems :

Thus could the Pascal with a "love of poverty" emerge;

and, simultaneously the eternal one remembered by those, philosophers not excluded, who skip on his twenties, presumably on account of their scientific content. Half-right, half-wrong.

Pascal's stay in Port-Royal further transformed an engineer able to build, into a philosopher able to think technological creations, including their own. (And, God!, the "infinite being".)

With Augustine, just as with Michel Foucault, we could say that Pascal was someone who wrote to progress, and progressed as they wrote... 


\section{ADVIS}

Necessaire à ceux qui auront curiosité de voir la Machine Arithmétique, et de s'en servir.

Amy lecteur, cet advertissement servira pour te faire sçavoir que j'expose au public une petite Machine de mon invention, par le moyen de laquelle seule tu pourras, sans peine quelconque, faire toutes les operations de l'Arithmetique, et te soulager du travail qui t'a souventes fois fatigué l'esprit, lorsque tu as operé par le jetton ou par la plume : je puis, sans presomption, esperer qu' elle ne te deplaira pas, apres que Monseigneur le Chancelier l'a honorée de son estime, et que, dans Paris, ceux qui sont les mieux versez aux mathematiques ne l'ont pas jugée indigne de leur approbation. Neantmoins, pour ne pas paroistre negligent à luy faire acquerir aussi la tienne, j’ay creu estre obligé de t'eclaircir sur toutes les difficultez que j'ay estimé capables de choquer ton sens lorsque tu prendras la peine de la considerer.

Je ne doute pas qu'apres l'avoir veuë, il ne tombe d'abord dans ta pensée que je devois avoir expliqué par escrit et sa construction, et son usage, et que, pour rendre ce discours intelligible, j'estois mesme obligé, suivant la methode des Geometres, de representer par figures les dimensions, la disposition et 
Enfin (cher lecteur), maintenant que j'estime l'avoir mise en estat d'estre veuë, et que mesme tu peux, si tu en as la curiosité, la voir et t'en servir, je te prie d'agreer la liberté que je prens d'esperer que la seule pensée à trouver une troisiesme methode pour faire toutes les operations arithmetiques, totalement nouvelle et qui n'a rien de commun avec les deux methodes vulgaires de la plume et du jetton, recevra de toy quelque estime et qu'en approuvant le dessein que j'ay eu de te plaire en te soulageant, tu me sçauras gré du soin quej'ay pris pour faire que toutes les operations, qui parles precedentes methodes sont penibles, composées, longues et peu certaines, deviennent faciles, simples, promptes et asseurées.

Les Curieux qui desireront voir une telle Machine s'addresseront s'il leur plaist au sieur de Roberval, Professeur ordinaire de Mathematiques au College Royal de France, qui leur fera voir succinctement \& gratuitement la facilité des Operations, en fera vendre, \& en enseignera l'usage.

Le dit Sieur de Roberval demeure au College Maistre Gervais, ruë du Foing, proche les Mathurins'. On le trouve tous les matins jusques à huict heures, \& les samedis toute l'apres disnée.

I. Les Mathurins étaient rue Saint-Jacques, attenant à l'hôtel de Cluny. Le collège de maître Gervais, dont les derniers vestiges disparurent lors de la création du boulevard Saint-Germain, avait été créé en 13 jo, par maître Gervais Chrétien, premier médecin ou physicien de Charles $\mathrm{V}$, et destiné particulièrement à l'enseignement de la médecine et de l'astrologie (Voir Franklin, Les anciennes Bibliothèques de Paris, t. II, I87o, p. 225). 


\section{HAPPINESS}

INSIDE THE WORLD. 


\title{
Happiness in the world? (Pascal before Port-Royal)
}

\author{
Camille Akmut
}

May 15, 2020

\begin{abstract}
Various events and people in the life of Pascal during his "worldly" period (here significantly revised, extended).
\end{abstract}




\section{People}

Jacqueline : the religious sister

Gilberte : the older, later married sister

Mersenne : 17th c. "router" of science... (Mersenne primes, that is him)

Christina : Queen of Sweden, patron of the sciences (possibly genderqueer)

Roberval : Professor of mathematics at the College de France

Desargues : another important mathematician of the time (geometry)

Saint-Cyran : founder of 'Jansenism', i.e. importer of Jansen's ideas in France

Jansen : Dutch. Strict Christian, reader of Augustine (S-C's buddy)

\section{Table of events}

\begin{tabular}{|l|l|}
\hline 1640 & 'Essay on conics' \\
1641 & Gilberte marries (Perier) \\
1642 & Machine for arithmetic [0] \\
1644 & Pascal shows off his Machine to the Prince of Conde [1] \\
1646 & Etienne Pascal injured. \\
1647 & First conversion [2] \\
1648 & Barometer experience [3] \\
1649 & Patents granted for the arithmetic machine \\
1651 & Death of his father. Inheritance \\
1652 & Jacqueline goes to Port-Royal [4] \\
1652 & Letter to the Queen of Sweden. \\
1654 & Vision. Final conversion \\
$1655 ; 56$ & Port-Royal; Lettres provinciales... \\
\hline
\end{tabular}

[0] Gilberte's biography (repeated by Brunschvicg/Boutroux, cf. Oeuvres 1 : 293).

[1] Brunschvicg/Boutroux vol. $3: 26$.

[2] Taton 1962.

[3] New Cambridge Early Modern History 4 : 157.

[4] Brunschvicg/Boutroux vol. 2 : front page.

\section{Table of events (2)}

\begin{tabular}{|l|l|}
\hline 1640 & Jansen, Augustinus. \\
$1643-1715$ & King Louis XIV's reign. \\
mid-1640's & Saint-Cyran, Letters... \\
1648 & Peace of Westphalia (end of the Thirty Years War). \\
1648 & Mersenne dies. \\
1650 & Descartes dies. \\
1654 & Letters from Jansen to Saint-Cyran published. \\
1654 & Christina of Sweden abdicates. \\
\hline
\end{tabular}


Brunschvicg/Boutroux put Pascal's "wordly" period between the death of his father and his final conversion ${ }^{1}$, ie. from about 1651 to 1654 .

But, this should rather be considered its height (being the last years before his retreat in Port-Royal).

This period can be extended to include most of his teens, twenties (with an interruption consisting of his first conversion).

\section{I - Early success (the boy genius)}

A basic overview of the field of mathematics during the times, and spaces, of Pascal can be gathered from the The New Cambridge Modern History :

Roberval, Desargues and Fermat are mentioned there as Descarte's "able rivals", while Gassendi had appeared just before. (Vol. 4, 48.)

Desargues plays an important role in the context of Pascal's early mathematical successes :

Jean Dieudonne, in his history of algebraic geometry, noted

"The originality of Desargues was that through central projection he found a way to move from particular cases of a theorem to its general formulation, for instance by obtaining general theorems on conics based on theorems relating to circles : thus Pascal, who was heavily influenced by the ideas of Desargues, could demonstrate his famed theorem on the hexagon" ${ }^{2}$

Here, a succinct description of Pascal's Essay on conics, implied :

$P_{1} P_{2} P_{3} P_{4} P_{5} P_{6}:$ a hexagon, "inscribed" in a conic,

\footnotetext{
${ }^{1}$ Brunschcq/Boutroux vol. $3: 112$.

${ }^{2}$ Dieudonne 1974 : 26.
} 
$K\left(P_{1} P_{2} \cap P_{4} P_{5}\right), L\left(P_{2} P_{3} \cap P_{5} P_{6}\right), M\left(P_{3} P_{4} \cap P_{6} P_{1}\right):$ the intersection points "of pairs of opposite sides",

$K, L, M$ lie on the same line (they are "collinear") ${ }^{3}$

- hexagon $=\operatorname{six}($ lat. hexa) sides...

- conic (section) $=$ the intersection of a plane with a cone

(this can be e.g. a circle, being a special case of an ellipse)

- e.g. $P_{1} P_{2}$, or $\mathrm{AB}=$ a side / line

$-\cap=$ intersection [possibly imported from set theory, or the other way around]

- inscribed $\neq$ inside, in (a shape can be in-side another without being inscribed)

Following these first accomplishments, during which he must have been 16-17,

Pascal repeated successes :

- Machine for arithmetic (1642, he is 19 years old $\left.{ }^{4}\right)$,

- barometers and pressure ${ }^{5}$ (1648, he is about 25), from which the namesake unit is derived,

- probabilities ${ }^{6}$, etc. etc..

We skip episodes such as when a 12-year old P. seemingly reinvented parts of maths :

Forbidden by Etienne from learning mathematics, a subject that "fills the mind with such great pleasure", in the fear his son should neglect his education in the humanities, Pascal invented his own mathematical terms e.g. to describe common geometrical shapes, and therefrom derived the rest.

"He begun to dream in his frees hours*; and being alone in a room where he had the habit to go for recreation, he took charcoal and started drawing on the windows, a perfect circle, a triangle whose

\footnotetext{
${ }^{3}$ Adapted from the textbook Geometry by its history, which teaches the subject following, close, historical order. (Desargues's theorem appears just before Pascal's.)

${ }^{4}$ Per Gilberte's biography.

5"Galileo's work was carried on by his pupil Evangelista Torricelli of Florence (1608-47) who constructed a barometer. The description given of it was vague, but it suggested ideas to Pascal which led not only to his barometric experiments, but to proofs of the more elementary propositions relating to the pressure exerted by fluids." (Cambridge modern history $5: 715$ )

${ }^{6}$ eg. Cambridge modern history 5 : 712 ("Before leaving the subject of Pure Mathematics")
} 
sides or angles are similar. (...) Once a terminology agreed upon, he started to create axioms ... and [at some point, finally] reached Euclid's 32nd proposition..."7

[*Meaning : outside of home-schooling.]

Fast-forward to the Pensees, and :

These earlier scientific achievements are what the mature Pascal must mean as part of the category of libido sciendi experiences :

"In the world everything is either lust for the flesh, desire to see

(know), or the hubris of life's conquests :

Libido sentiendi, libido sciendi, libido dominandi."

458 B

8

\section{II - A letter to a Queen}

Perhaps no other document of this entire period speaks so much truth to the state in which Pascal had been at the brink of his final conversion than the letter he sent to Christina of Sweden in 1652, so liquorish and outsized it needs no commentary but itself :

Letter to the Most Serene...

"Madam,

If I had as much health as zeal, I would present myself to Your

Majesty a work of many years, that I dare offer from afar; and

\footnotetext{
${ }^{7}$ Gilberte's biography has been repeatedly called a hagiography.

${ }^{8} \mathrm{~A}$ pensee that Condorcet (found so bad he) removed from his own edition of the Pensees, noting P. struck through it, noting also no one should miss it. (See Condorcet's "eloge"...)
} 
I would not suffer from any other hands than mine the honor of bringing it to the feet of the greatest princess of the world.

This work, Madam, is a machine to do arithmetic...;

and I cannot better describe it than by saying that I put as much work into it than if I knew that one day it would appear before person as august as you.

Yet, Madam, if this had not been my intent, it would be its reward. And, I would consider myself too lucky, if after so many sleepless nights ["veilles"], it could bring Your Majesty just a few moments of satisfaction..." etc. etc..

(If philosophers actually read philosophers, including their patents, and letters such as this one, they would do much better work...)

The sender of this monumental letter known, its object too (the Machine for arithmetic) : its recipient is in fact very fascinating (so much that "the greatest princess of the world" may not have been that much of an exaggeration) :

"Queen Christina of Sweden, ... patron and disciple of Descartes, ...

correspondent of Pascal and Spinoza"

— is more or less her usual description ${ }^{9}$.

She is in turn described by Brunschvicg/Boutroux as Europe's most in-vogue personality... ("la plus en vue") ${ }^{10}$. In other words : an intellectual, ruler, and glamorous.

\footnotetext{
${ }^{9}$ As found in the textbook The Cambridge Modern History (Vol. 5 : 744 (Section "Jesuits and their converts")

${ }^{10}$ Brunschvicg/Boutroux vol. $3: 26$.
} 
It was to this person, no other than the Queen of Sweden, that a 29-year old Pascal decided to send a letter - and what letter.

Christina was fascinating for many other reasons : Of them we are further told :

"She was educated as a male, learning to ride, fence, and shoot;

(...) By 1650 Christina had made it clear she could not marry. This

decision arose from her own identity struggles, which may have been

complicated by psychological and physiological factors." 11

raising the possibility that she may have been genderqueer, or non-straight, or any combination of the above.

In the background of this exchange lies the Thirty Years War (1618-1648), and, later, her abdication in $1654 .^{12}$

\section{III - A visit to a Prince (marketing of the Machine, cont.)}

Before Pascal had "presented" his Machine to the Queen of Sweden, he had already done the same for the Prince of Conde eight years earlier;

At least he had received an invitation to do so, stating when exactly the said Prince was best visited.

It came from a Bourdelot, "French preacher and doctor"13 ("abbot"14). The same had already been involved with (playing intermediaries with) the Queen.

\section{"Monsieur,}

\footnotetext{
${ }^{11}$ Encyclopedia of the Early..., vol. 1.

${ }^{12}$ The chronology provided at the end of volume 5 of The Cambridge Modern History holds 1652 , but this seems to be an error. (Elsewhere in the text, so far as we recall, 1654 is given. In Encyclopedia of the Early... that same date is also repeated.)

${ }^{13}$ Les Lettres de, footnote in the Letter to the Queen.

${ }^{14}$ Oeuvres.
} 
I was speaking to His Highness ["Son Altesse"] yesterday who com-

municated to me his impatience to see your [Machine] ${ }^{15}$. If you will please come tomorrow at 10 in the morning, I believe it will be most convenient to [said Highness]."

(letter from 1644)

"You write mighty well for a philosopher..."

[the Queen likes your stuff, etc.]

(letter from 1652)

[The Prince of Conde must have been Henri II, by that time (does it really matter? $\left.\left.{ }^{16}\right) \ldots\right]$

\section{IV - Pascal's correspondence : social capital (2)}

Pascal did make great, continuous use of his father's vast network of connections (bridging the scientific and political worlds) :

It was through him that he was able to access most of his early supporters including Roberval (who would later act as a seller-demonstrator for the Machine), and interlocutors.

Pascal's network - as can be ascertained from his correspondence - included dozens of important figures of the time;

in addition to already mentioned Fermat, the Queen of Sweden and Prince of Conde :

Mersenne, Descartes, Christiaan Huygens, Christopher Wren,... ${ }^{17}$

A letter sent by Descartes to Mersenne, from December 1647, gives us an insight into these happenings :

\footnotetext{
${ }^{15}$ In this document the Machine is called "roue Pascal".

${ }^{16}$ In 'The Cambridge modern history', old and new, the (various) Princes of Conde are found.

${ }^{17}$ See our bibliography.
} 
"Dear Father [Mersenne]

It has been some time already since M. of Zuylichem has sent me the print by Pascal, for which I thank the author, as it is they who send

it.

\section{From Egmond"}

It is useful to remember that Descartes was then in the Netherlands ${ }^{18}$, having fled France. Hence why Huygens, presumably. But, more importantly :

To sum up what is happening :

1. Descartes via Mersenne discusses Pascal (and likely vice-versa);

2. Huygens ["M. de Zuylichem"], in turn, played intermediaries for Pascal and Descartes;

3. Add whatever intermediary steps this letter required but does not mention.

This is how a highly resourceful network looks like; and what is meant by high social capital : just as an individual may possess economic capital (of which Pascal, bourgeois-noble, had lots of both).

Bourdelot introduced Pascal to the Prince of Conde, and again is mentioned by Pascal in his letter to the Queen of Sweden - B. was "in good favors" with her, we know from Pascal editors ${ }^{19}$.

Pascal before navigating complicated philosophical arguments, knew how to navigate the world...

*** Origins of the Machine for arithmetic? ***

\footnotetext{
${ }^{18}$ See e.g. Cambridge Modern History 4, 779 : "He [descartes] remained in Holland until September 5, 1649 ... At the same time he was in correspondence with several learned men; with his friend Father Mersenne, who formed a centre of scientific correspondence; with Fermat and Roberval ..."

${ }^{19}$ Les Lettres de Blaise Pascal, p. 182.
} 
At the center of this network of various scientists, and others, lied Marin Mersenne, who

"from 1620 to 1648, [kept] a vast and systematic scientific correspondence by which he maintained a flow of news of scientific discoveries and ideas between most of the leading scientists of the day. (...) as far apart as Sweden, Poland, and the Levant." 20

Did pascal know of Schickard through his father via Mersenne?

This is the question that was asked by historian of sciences Jean Itard in a book review from 1960, noting that the - by then published - large correspondence of Mersenne contained mentions of Schickard.

This seems plausible considering this is how he learned of Torricelli ${ }^{21}$.

\section{Scientific societies : social capital (3)}

The institution of the scientific society played an important role in our context :

Among them, Marin Mersenne's society, or group, was a major one ${ }^{22}$ : Academie Parisienne / Academia Parisiensis - created 1635.

He had "made his cell in the convent near Place Royale (now Place des Vosges) both a meeting place for scientific discussions and experiments" 23 .

Note these societies - some of them at least - seemed to have been much less sumptuous than current ones; and this may, or may not serve as lesson to our most distinguished current-day learned gentlemen and -women.

\footnotetext{
${ }^{20}$ New Cambridge Modern history 4, 141.

21 "To Pascal, who learned of Torricelli's work from Mersenne, this suggested a simple but striking test for the hypothesis: the air pressure, and therefore the height of the mercury, should be less at the peak of a mountain than at its foot. In 1648 the experiment was successfully carried out on the Puy-de-Dome by Florin Perier." [his brother-in-law] (New Cambridge Modern... 4, 157)

${ }^{22}$ qualified "important forerunner" to the French Academy of sciences in Encyclopedia of the Early Modern World.

${ }^{23}$ New Cambridge modern history 4, 141.
} 
They "met on Thursdays and [the event] was attended by the outstanding scientists and mathematicians of his day." 24

In 1666, the French Academy of Science was created, under Louis XIV, formalizing such societies. - but also bringing them under (State) control, and arguably making them inaccessible.

\section{V - Loss of father and sisters, and entourage}

In just one year Pascal lived to see the death of his father (1650), and the departure of his only remaining sister, Jacqueline (1651); while Gilberte had been married for almost ten years at that point.

For fear of overestimating we should not underestimate, and these facts should be seen as relevant background for his decision-making.

Through religion, in particular Port-Royal's variant of Jansenism, he found a way to deal with these events, we can assert.

In the letter written to Gilberte and her husband right after his father's death :

"We lost him the day he was baptized."

Preceded by a revocation of philosophy :

"Seneca and Socrates have nothing covincing to tell us on this occasion. (...) They all took death as natural (...) Does this not show

how weak Men are, if the greatest creations of the greatest among

them are so low and puerile.

Jesus-Christ, however, ...

Without [them] death is horrible, and horror within nature"

${ }^{24}$ Encyclopedia of the Early... vol. 4. See also Clere 1835. 
His father's death was suddenly put in a logical, coherent, and bearable perhaps too, context (at least temporarily);

While by later moving to Port-Royal, he got closer to Jacqueline. Gilberte, long married, was further out of reach.

Brunschvicg/Boutroux made the interesting remark that it was precisely when Jacqueline's fervor to enter the religious professions was the highest that her brother's worldly ambitions seem to have been the greatest ${ }^{25}$.

It should also be noted that this same period (end of 1640's, beginning of the 1650's) saw the death of Mersenne and Descartes; as well as the abdication of the Queen of Sweden;

Further isolating Pascal. Death, the ends of life, and connected topics, were not merely a theoretical subject at this point in the life of Pascal.

They lead straight to 1655 and provide another useful background for the moods and contents of the Pensees (in addition to Pascal's own health).

\section{VI - Etienne's injury (Rossellini's Pascal commented)}

In this dramatization, Etienne Pascal's injury coincides with a manifestation of Pascal's illness, and can be seen as a turning point :

During his father's treatment Blaise looses consciousness, and the (Jansenist) doctors examine him. Through Jacqueline, who tends to him, he receives from them St-Cyran's writings. [Segment 1]

Pascal's transition is most visible in a later segment, occurring apprx. 20 minutes afterwards, when, drawing water from a well, he enters an argument with his sister Jacqueline about his new-found views : his often mentioned "love of poverty", etc.. [Segment 2]

\footnotetext{
${ }^{25}$ Brunschvicg/Boutroux vol. $3: 25$.
} 
[Segment 'Doctor's visit']

- If we are indeed experts in anatomy, a science learned on the battlefields we know nothing of such afflictions ("humeur")... Here the Letters of Saint-Cyran, a French disciple of Jansen. They should leave the sick at no time.

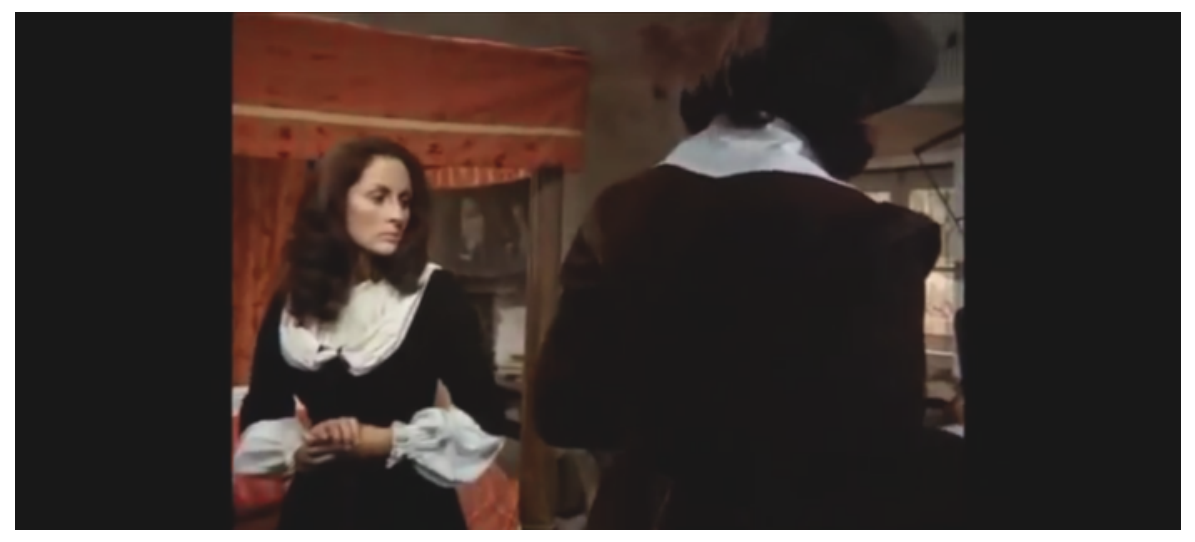

Figure 1: Doctor's visit (Blaise Pascal)

[Segment 'Argument at the well']

- But, why not have your valet do it? You tire yourself without reason...

- I have a wish for poverty :

Actions are worth more than any discourses, in this regard.

- But, you forget that poverty which affects the mind!

And, until now you did not seem to care to cultivate such a disposition,

neither in your actions, nor your thoughts. Is this not one of your contradictions?

- ... emptiness is only a representation of infinity.

("le vide n'est que la figure de l'infini")

... Do you ever love someone by reason alone?

In Rossellini's Blaise Pascal, Etienne's leg seems to be injured; while the doctors are the "Deschamps" brothers.

Continuing this theme of historical (in)accuracy :

The "Letters of Saint-Cyran" could refer either to letters received or sent by the abbot of Saint-Cyran; 
in the former case La naissance du jansenisme decouverte, published in 1654, was a notable work as it contained Jansen's letters to Saint-Cyran - some of the most important documents when it comes to the reception of Jansen's ideas.

Though this would not fit the chronology, Etienne's injury happened much earlier.

Most likely the Lettres chretiennes are meant, published in the 1640's (fitting with the events). [S-C sent a lot of letters to a lot of people $]^{26}$

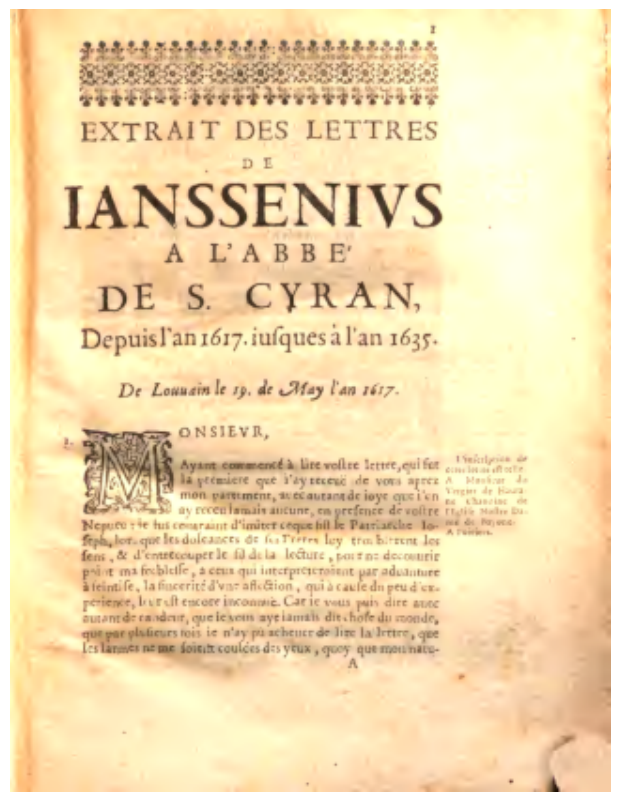

Figure 2: Jansen - Saint-Cyran letters... (1654, Leuven)

(And, when one of the doctors claims to have learned his science, medicine or anatomy, on the fields of battle, he almost certainly means the Thirthy Years War, which by the time of Etienne's injury was still raging on...)

\footnotetext{
${ }^{26}$ For a discussion of this, see Bremond 1967, in particular vol. 4 : 85-86; 46... [Bredmond's appraisal of Saint-Cyran is at least on par with Condorcet's evaluation of Pascal.]
} 


\section{* Sociology of the Father Mersenne}

On the social spectrum, Mersenne represents the exact opposite of Pascal, with his upper-class origins, and father mathematician (in short, the very unsurprising origins of too many mathematicians to $\operatorname{count}^{27}$ );

Called agreably "“gentlemen of private means"" in textbooks by respectable historians... ${ }^{28}$.

(What one should call "bourgeois-friendly" history textbooks in a parallelism with the "white-oriented" ones critized by the well-known historian from Boston.)

As such, our Pere Mersenne merits a more detailed portrait :

His father was a farmer, and it was through education - a very good Jesuit school - that he was able to become more than he should have.

The same school of La Fleche, supported by Henri-IV, that Descartes would also later attend ${ }^{29}$.

This school had the characteristic - shared with all Jesuit schools - of being free of charge (for pupils who lived outside i.e. "externe");

A feature that permitted Jesuits to attract pupils ${ }^{30}$, and which made them attractive for lower-class folks. (Something that created discontent amongst those who opposed the Jesuits / were proponents of a paid education (for the rich)).

Mersenne happened to live 5 leagues ["lieue"] from that School ${ }^{31}$ (about 10 miles or $15 \mathrm{~km})$.

Following this and two years of further studies at the Sorbonne ${ }^{32}$, thus joined

\footnotetext{
${ }^{27}$ whose sociological regularities are almost as strong as their mathematical laws... (contra whatever Romantic notions of exceptionalism, and even "genius" they may entertain... Like some animals, who, looking at their reflection, do not recognize themselves...)

${ }^{28}$ New Cambridge Early Modern history 4, 133.

${ }^{29} 3$ months later (Clere 1853 : 108).

${ }^{30}$ Clere 1853: 86.

${ }^{31}$ Clere $1853: 108$

${ }^{32}$ Encyclopedia of the Early... vol. 4.
} 
the religious professions : the closest to an intellectual profession for those who were not financially independent, like the aforementioned bourgeois philosophers...

Specifically Mersenne chose a mendicant order (called "minim", or "very small') which is to say the type that were closest to people (they had to be, to receive donations) and lived by vow of poverty.

[A better known such group is the order of Saint Francis, the so-called "Franciscans".]

In this 17th century, Mersenne is to mathematics what Racine is to letters...; While Moliere in turn was much closer to Pascal in terms of social origins, as were most other writer-philosophers (including Montaigne, Condorcet, Marquis, La Rochefoucauld, "prince", etc.).

It takes not only a solid mind do science or to write, it also takes time, and that time must be paid for somehow — inheritance or work permitting spiritual activities...

As soon as Mersenne had a stable position (were are told he became a teacher in the convent in 1614, first in the province then in Paris, 1619), he could begin his prolific scientific activities, both as a maker of science and arguably even more importantly as a relay of scientific communication.

If the Encyclopedie, as we had already proposed, prefigured some sort of Internet / Web; Mersenne was more like a router or node of information, a principal, very active ${ }^{33}$ one.

And, if the Port-Royal logic was the most fascinating and underestimated work of this period, then Mersenne is its most intriguing yet barely known figure.

\footnotetext{
${ }^{33}$ The editors of the New Cambridge Modern History call him "indefatigable" $(5,47)$.
} 


\section{Afterword}

Condorcet concluded in his strange 'Eloge' :

"Pascal had reached a point of perfection : [he needed] to love no one, and wanted to be loved by no one."

However right he was, Pascal reminds us of our modern heroes of the 21st century the most [which we would rather reference than produce yet another copy of Brueghel and Ruben's five senses paintings]...

As we must all, after all, live in our century. - Pascal had lived in his own, the 17 th.

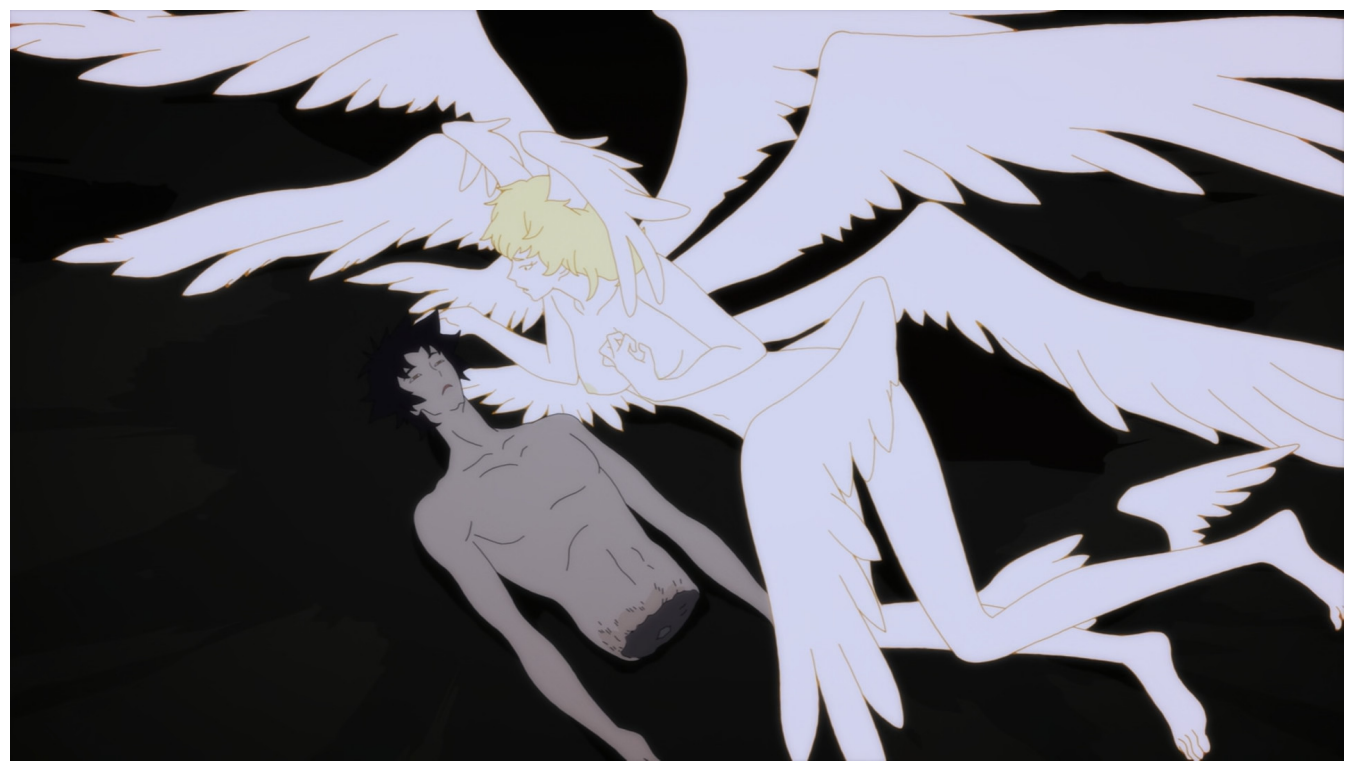

("Why is it that I feel something now...") 


\section{Bibliography, partial}

\section{Primary sources}

Pascal, Blaise.

- 1651. 17th of October. 'Letter to Mr. and Mrs. Perier' [Father's death] e.g. Brunschvicg/Boutroux vol. 2 : 537ff..

- 1652. C. June. 'Letter to Christina, Queen of Sweden'. e.g. Brunschvicg/Boutroux vol. 3 : 25ff..

- 1654. 27th of October. ['Letter to Fermat'] e.g. Brunschvicg/Boutroux vol. 3 : 429ff..

(The first four volumes of Oeuvres are generally relevant for this period.)

-. 1922. Les Lettres de Blaise Pascal ['together with those of his correspondants']. Ed. Cres.

(About 50 letters. The editors prefaced this compilation with the words "Even though the Provincials and the Pensees are in every hands, the whole of the correspondence of Blaise Pascal remains little known to the public. ..."; the Oeuvres, these editors note, have the entirety of the letters - but it sure is nice to have them in one small book, rather than split over many volumes)

Bourdelot.

- 1644. 26th of February. 'Letter from Bourdelot to Pascal'. [Invitation to see the Prince of Conde]

e.g. Brunschvicg/Boutroux Oeuvres 1: 283.

- 1652. 14th of May. 'Letter from Sweden, Bourdelot to Pascal'. [Regarding the Queen]

e.g. Brunschvicg/Boutroux vol. $3: 27-8$.

Descartes.

- 1647. 13th of December. 'Letter to Mersenne' [about Pascal] e.g. Les Lettres de Blaise Pascal, appendix 1.

* Brueghel - Rubens. Early 17th c.. Sight.

(Instruments, maps, globes on one side; art on the other. Desire to know, and see...)

* Harvey. 1628. On the motion of the heart and blood in animals

(In his writings on infinity, (Pensees), Pascal evoked the composition of blood, as part of developments on what cannot be seen through "common senses" (MS c p 348).) 
* Jansen - Saint-Cyran correspondence. In : 1654. La naissance du jansenisme decouverte ['The Birth of Jansenism discovered']. Louvain.

(Contains also some more minor letters sent by others, at the end.)

* Saint-Cyran. 1640's. Lettres chretiennes et spirituelles. (multiple editions)

Brief remarks on English translations

- An English translation of the Faugere ed. of the Pensees was available at the latest by 1885 (done by a C. K. Paul)

[gathered from the bibliography of The Cambridge Modern History]

- An English translation of the Lettres Provinciales was available at the latest by 1880 (De Soyres).

[the editors of The Cambridge Modern History were aware of it as well]

\section{Bibliography}

- Bremond, Henri. Histoire du sentiment religieux en France. Many vol..

-. 1967. Vol. 4. Colin.

(Ch. 3, 4, 5 are about Saint-Cyran.)

- Cavailles, Jean. ['Axiomatic method and formalism']. Ch. 1, 66 ff..

(On Pascal's theorem, Desargues' theorem (and Hilbert))

- Clere, Jules. 1853. Histoire de l'Ecole de La Fleche... / 'History of the School at La Fleche, from its foundation by Henri IV to...'. Jourdain.

(In particular ch. 3, "The old college under the Jesuits (1604-1622)", and even more so the section "Descartes and Mersenne", in inverted order of attendance, (comparatively little on Mersenne))

- Condorcet. 1847. Oeuvres. Many vol.. Firmin etc..

- Vol. 3. (For the strange "eloge", eulogy of Pascal - whose preface is an absolute riot, so much so the editors weighed whether to remove it)

-. Vol. 2. (For the eloge of Roberval)

- (ed.) Pensees.

- Dieudonne, Jean. 1974. Cours de geometrie algebrique. T. 1 "Apercu historique...". PUF.

(Bourbaki group member. The history of algebraic geometry from Antiquity to today. Divisions into 7 periods. Contains developments on Desargues, Pascal...)

[An English translation is available under the title History of algebraic geometry.]

- Itard, Jean. 1960. "Correspondance du P. Marin Mersenne, religieux minime, t. V (1635)" Revue d'histoire des sciences 13(4) : 355-357.

(Book review in which Itard makes the important note that Mersenne's large correspondence included some with Schickard, spelled "Schickart". When he addresses "the historians of such [computing] machines", and prompts them to 
research further, with little doubt he must have had Rene Taton in mind (who headed the journal and whose domain it was))

- Ostermann / Wanner. 2012. Geometry by its history. Springer.

- Rossellini, Roberto. 1972. Blaise Pascal.

(The commented scenes happen at c. 40 min. and 1 hour, respectively.)

-. 1966. The Taking of Power by Louis XIV.

-. 1972. Augustine of Hippo.

-. 1974. Cartesius.

(by the same director, also relevant; part of his historical (TV) films period. Preceded by Francis a.o.)

- The Cambridge Modern History. Cambridge Press.

—. 1906. Vol. 4: "The Thirty Years' War".

—. 1908. Vol. 5: "The age of Louis XIV". (ch. 23 : "European science...")

- The New Cambridge Modern History. Cambridge Press.

- 1970. Vol. 4 : "The Decline of Spain and the Thirty Years War 1609-48".

-. 1922. Vol. 5 : "The ascendancy of France 1648-88".

\section{Illustrations}

Devilman Crybaby (Science Saru)

Castlevania: Symphony of the Night (Konami) 


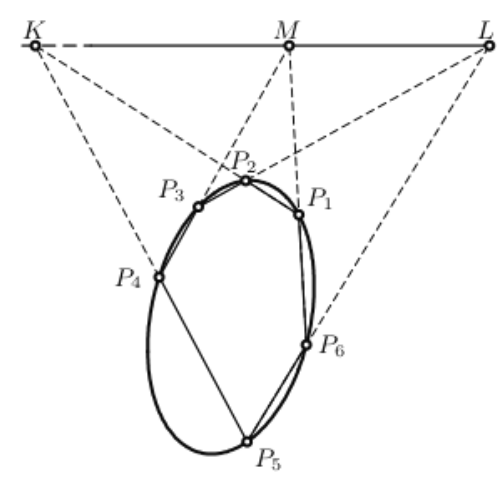

Figure 3: Drawing by Ostermann / Wanner

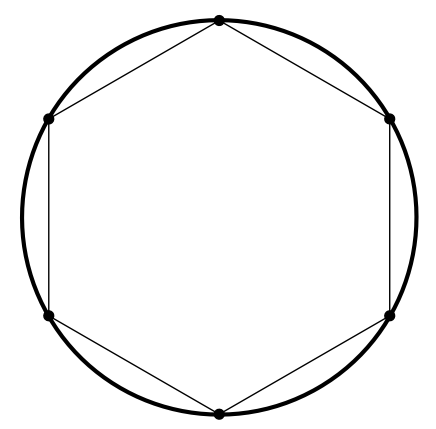

(A most special case : a regular hexagon inscribed in a circle) 


\section{PRIVILEGE}

POUR LA MACHINE ARITHMETIQUe dE M. PASCAL

Louis, par la grace de Dieu, roy de France et de Navarre, á nos amez et feaux Cons ${ }^{\text {rs }}$ les gens tenans nos Cours de Parlement, $M^{\text {es }}$ des Resquestes Ordinaires de nostre hostel, Baillifs, Senechaux, Prevôts, leurs Lieutens et tous autres nos justiciers et officiers qu'il appartiendra, salut. Notre cher et bien améle $S^{r}$ Pascal nous a fait remontrer qu'àl'imitation du $S^{r}$ Pascal, son pere, notre Cons ${ }^{\mathrm{r}}$ en nos conseils, et president en notre Cour des Aydes d'Auvergne, il auroit eu, des ses plus jeunes années, une inclination particuliere aux sciences Mathematiques, danslesquelles, par ses etudes et ses observations, il a inventé plusieurs choses, et particulierement une machine, par le moyen de laquelle on peut faire toutes sortes de supputations, Additions, Soustractions, Multiplications, Divisions, et toutes les autres Regles d'Arithmetique, tant en nombre entier que rompu, sans se servir de plume ni jettons, par une methode beaucoup plus simple, plus facile à apprendre, plus promple à l'execution, et moins penible à l'esprit que les autres façons de calculer qui ont esté en usage jusqu'à present; et qui, outre ces avantages, a encore celuy d'estre hors de tout danger d'erreur, qui est la condition la plus importante de toutes dans les calculs. De laquelle machine il auroit fait plus de cinquante modeles, tous differens, les uns composez de verges ou lamines droites, d'autres de courbes, d'autres avec des chaisnes; les uns avec des roüages concentriques, d'autres avec des excentriques, les uns mouvans en ligne droite, d'autres circulairement, les uns en cones, d'autres en cylindres, et d'autres tout differens de ceux-là, soit pour la matiere, soit pour la figure, soit pour le mouvement: de toutes lesquelles 


\section{PENSEES \\ PROOF OF INFINITY.}




\title{
Pascal's Pensees : problems of edition, problems of interpretation.
}

Camille Akmut

May 5, 2020

\begin{abstract}
Summary of editorial and interpretative issues - then and now. Cousin's 1842 Report; Pensees as seen by contemporaries up to about Nietzsche...
\end{abstract}




\section{I - Problems of edition}

Modern editions of the Pensees may sometimes give the reader the impression of a unified book;

Older ones made such a false notion more difficult : they held variously, on the front page, or elsewhere, as title or otherwise :

"Thoughts of Mr. Pascal, on religion, and other subjects, having been discovered after his death amongst his papers [reviewed and corrected anew/once more]"

such as this one from 1694 (published in Lyon).

In fact they were fragments, many of them. He [Pascal] would also sometimes dictate his thoughts to others ${ }^{1}$.

Victor Cousin ${ }^{2}$, more than anyone, early on, had highlighted the many issues surrounding the Pensees.

His Report to the French Academy from 1842 remains an important reading for anyone wishing to understand this work's complicated nature and background.

These problems can be summed up as, generally :

- Uncertain order of the notes/thoughts (dubious existing classifications)

- Early editions diverge from the Manuscript; alterations

- What sources and classification to use, in the future.

- [Hard to read, decipher the Manuscript ${ }^{3}$ - the least of issues?]

Among these problems emerges as the most dramatic : suppressions (in

\footnotetext{
${ }^{1}$ This last information we gathered from Cousin's report (p. 10).

219 th c. philosopher and education administrator.

${ }^{3}$ p. 10 , and e.g. 91 again for a specific example.
} 
addition to omissions), on one hand, combined with alterations or additions on the other, and relocations yet ${ }^{4}$ among others.

They are associated with two editions : the 1669 Port-Royal edition (established by family and friends of Pascal) and Bossut's 1779 one $^{5}$, which served as basis for all other ones and constituted the dominant understanding of Pascal's work.

Here one of Cousin's memorable moments in his report, in this regard :

"Imagine if Plato's original manuscript was - known to all - available in a public library, and yet no one cared, and everyone, year after year, reproduced the same [fake] editions, without ever asking themselves questions; and discussed or admired this or that passage of the Pensees, or finer point of Pascal's thought [based on illusions]. Yet this is exactly where we are when it comes to the Pensees ... Go take a look at the Royal library [on Richelieu street], it's not far away" [and convince yourself of the major differences] ${ }^{6}$

From his Report, two passages can be taken to illustrate this (that struck us as particularly bad) :

- Suppressions

an entire c. 15 lines long passage is simply erased by the P-R editors; in which Pascal expounded on his thought "Montaigne was wrong; customs should only be followed because they are customs, not because they are reasonable..."7

- Additions

${ }^{4} \mathrm{As}$ in the case of Bossut, who put a fragment as supplementary material (Cousin report 46) (See also p. 208 for a Port-Royal relocation.)

${ }^{5}$ Charles Bossut (1730-1814)

${ }^{6}$ Pp. $9 \mathrm{ff}$.

${ }^{7}$ Cousin 1842 : 168-169. (P-R "a supprime tout ce morceau") 
it gets even worse; a single sentence of Pascal, in turn, [the one on Pyrrhus receiving advice on rest (not needing a conquest)], is turned into a page! once passed through the hands of the most zealous P-R editors... ${ }^{8}$

139 B / Manuscript p10

"The advice that had been given to Pyrrhus to take the rest he was seeking through a many [hardous tasks], met great difficulties."

Port Royal

"That is why when Cineas told Pyrrhus, who had proposed to take his rest amongst friends once done conquering the World, that it would be better to enjoy his happiness now" etc. etc. etc.

In Cousin's view, an authentic version of the Pensees could be found in the intersection of the two dominant editions (of his time) and the Manuscript ${ }^{9}$ :

$\{$ Port-Royal ed. $\} \cap\{$ Bossut ed. $\} \cap\{$ Manuscript $\}=$ the 'real' Pensees...

He estimated, to have established "irrefutably", that one quarter up to one third of the Pensees (as they were commonly understood to be) were foreign to that work. ${ }^{10}$

Cousin also mentions errors of Pascal corrected by P-R; those corrections he judges favorably. ${ }^{11}$

To give one example : at some point Pascal addresses a possibly real person, in what appears to be an attack, and Cousin agrees with P-R this should not be included (in that great work...). This is contestable.

\footnotetext{
${ }^{8}$ Cousin $1842: 105$.

${ }^{9}$ Cousin 1842: 71

${ }^{10}$ Cousin 1842 : 70. See also p. 24 for more details on the same.

${ }^{11}$ Cousin 1842 : c. pp. 90-91.
} 
On the other hand, when Pascal himself strikes through some of his own passages e.g.

924 B / Manuscript p344

"People with no word, no faith... two hearts, and the same ambiguity

in their language; like the faboulous amphibian animal. Half-birds, half-fishes."

Cousin feels they should stay ("On ne voit pas pourquoi" etc. etc.) ${ }^{12}$.

Not everything done by Cousin was perfect, and yet he created the first modern, scientific edition, and contributed to a major leap in our understanding of Pascal's complicated work.

[To say nothing of English translations, and delays in Pascal's reception in the English-speaking world.

That e.g. Russell may have been ignorant of Pascal comes both out of lack of knowledge and stupidity i.e. he had not had sufficient access to Pascal's work and hated him. Increasingly it appears to us that all that Russel may have known of Pascal was whatever he had read in Nietzsche... (And, even Nietzsche he might have read in the wrong places...)]

\section{II - Interpretative problems, Contemporaries to Nietzsche}

In 1670, Etienne Perier, the son of Pascal's sister (not to be confused with the other Etienne, father of Blaise), wrote a preface for the Pensees, noting :

"M. Pascal, having left the study of mathematics at a young age, and of physics, and the other profane sciences, in which he had made

\footnotetext{
${ }^{12}$ Cousin 1842 : 200.
} 
such considerable progress, and such that no one could claim to have gone as far as he had in the matters that were his, begun, around his thirstiest year, to apply himself to more serious and elevated matters".

Religion and its study was meant.

This was proposed as interpretation, following the death of Etienne's grandfather a few years earlier.

Some centuries later a provincial professor sought to revolutionize the understanding of the Pensees, this seemed very important to him for he made sure to specify the year that this idea had been proposed by him (a now obscure figure) :

"I attack the traditional thesis : that the Pensees, had Pascal had the time to complete them, would have been an apology of Catholicism, and only that"

And, yet, Souriau merely attempted to debate the finer points of religious controversies : in his view the Pensees aimed to establish the "truth" of Jansenism, as part of a dogmatic section, and to defend Port-Royal against its enemies, in a more polemical one. ${ }^{13}$

Cousin himself noted that Pascal's project was vast enough ["son dessein"] to include the most diverse of thoughts ${ }^{14}$.

Boutroux, addressing another commentator of Pascal, noted how (about) everyone were able to find their own ideas in Pascal. ${ }^{15}$

In the view of Cousin it was Descartes who put an end to philosophy and literature (as they had been organized hitherto in the Renaissance), through formal innovations (by his language, e.g. abandonment of pomp), but Pascal who pushed this breach with tradition the furthest. ${ }^{16}$

\footnotetext{
${ }^{13}$ Souriau $1896: 5$ (and surrounding)

${ }^{14}$ Cousin $1842: 22$

${ }^{15}$ Letter to Giraud. (Cited in Giraud 1905 : vii)

${ }^{16}$ Report, pp. 4-5.
} 
By the time the cleverest-of-all Nietzsche came along, Pascal was pronounced dead and buried, and unburied, a thousand times over again.

"The greatest and most deplorable example" of what Christianity could do to a thinker...

Relegated forever to the back pages of history.

Russell used the dead Nietzsche to hammer on the even more dead Pascal.

\section{III - More positive things?}

We stated that many end up gravitating towards Pascal : should people look at Pascal for philosophical guidance?

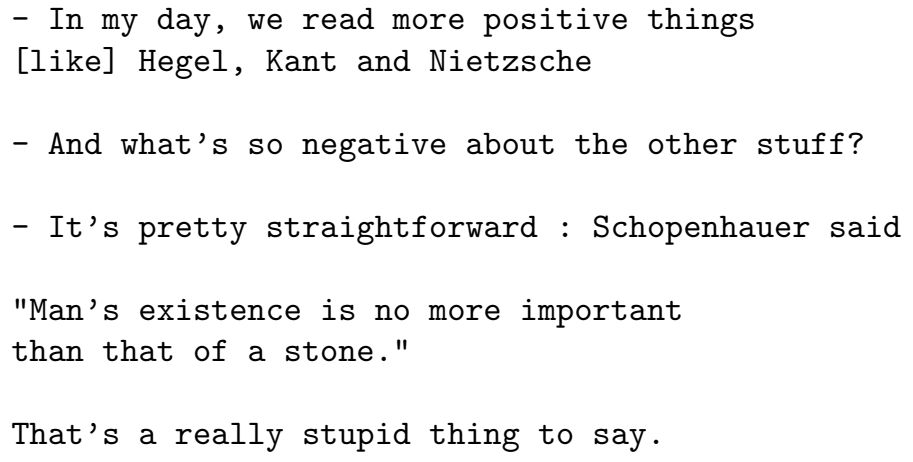

17

This is dialogue from The third generation, whose themes cover technology, including computers and philosophy ${ }^{18}$ :

But, if this were a work of the French new wave Pascal might have very well replaced Schopenhauer's role.

\footnotetext{
17 [Adapted and revised from random Blu-ray subtitles.]

${ }^{18}$ For capitalistic reasons, a computer technology entrepreneur funds a terrorist group (by 'third generation' contemporaries knew the RAF was meant) in times of "“alarmism against mass data collection"" ("Hetze") - as he put it. (Another Schopenhauer quote serves as secret/code.)
} 
If indeed "we all live in a great asylum for the insane" as Pascal purportedely expressed $^{19}$ - then none of this should matter.

$414 \mathrm{~B}$

"... to not be insane would be insane by some other turn of folly."

[It would be crazy to not be crazy $]^{20}$

he did write.

A thought that should in turn make him appealing (again) for anarchists.

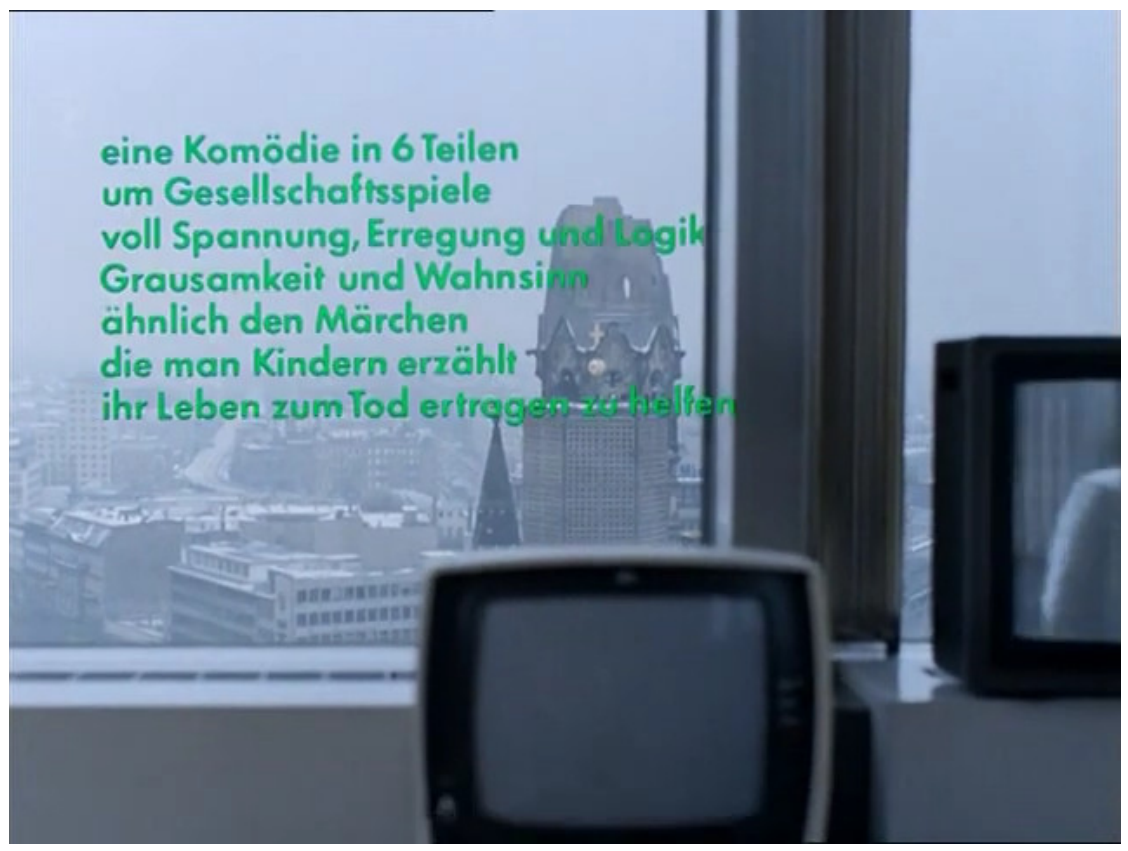

\footnotetext{
${ }^{19}$ Found in the introduction to Celine's Semmwelweis (all ways strangely lead back to Pascal). Possibly an interpretation of $82,331,414 \ldots$ [Pascal wrote a lot on folly]

${ }^{20}$ Huxley, using the work of social psychologists, would later echo these thoughts.
} 
To all of them, Pascal would have answered, and did answer already :

Manuscript $\mathrm{p} 61$

"Atheism, sign of a strong mind, but only to a certain degree."

Nietzsche, so clever and well-read and knower of so many languages, thought he had understood the poor Pascal better than he himself had done, but not quite so;

It had not escaped Pascal what complicated situation he was in, and yet :

For Pascal, believing was hard, while not believing was easy...

Marxists and anarchists alike should find in Pascal a new companion :

Just like them he had accepted the importance of making uncompromising choices. 
Pensees : proof of infinity.

Camille Akmut

May 7, 2020 


\section{I - The topic of infinity in the Pensees}

In the order of the Manuscript it is the topic of infinity that opens the Pensees.

While in the context of the copy, (C1), it is part of an unordered series for which we have the information that "Pascal had long carried it inside his pockets" - the only series of its kind for which we have such an indication.

One way or the other there seems to be something special about these notes on infinity.



Figure 1: Manuscript p3 (Bibliotheque Nationale)

Retranscription :

"Infini rien

$<$ separation line $>$

notre ame est jetee dans le corps ou elle...

$<$ separation line $>$

... unite jointe a l'infini ...."

A reader of the thematical edition, Brunschvicg's, or any other, may never know, for instance :

Brunschvicg begins with the difference between the 'two kinds of minds'.

The thoughts on infinity, there, are gathered in, later, section II. ${ }^{2}$

\footnotetext{
${ }^{1}$ [which, as a by-note, may explain why it is so often cited (a somewhat artificial status)]

${ }^{2} 233$ and surrounding.
} 
Lafuma has accurately described their material aspects : not as much small notes, as larger papers separated by lines (headed by crosses). ${ }^{3}$

Here our translation of the third thought (from top to bottom, in the order of the manuscript) :

Manuscript beginning - ...

"A unit added to infinity does not augment it in any way ... Finite, in the presence of infinite is anihilated; and becomes pure nothing ["neant"];

Such is our spirit in front of God; and our justice before divine one.

We know that there is an infinite and [yet] ignore its nature; in the same way that we know to be false [the idea] that numbers are finite : hence there is an infinite in numbers; we [just] do not know what it is;

it is false [to say] that it is odd; as adding a unit to it wouldn't change its nature at all. Yet it is a number, and any number is either even or odd. It is true that this applies ["cela s'entend"] to finite numbers. It is so that we can know that there is a God without knowing what he/it/they/she is. ["il"]

Fragments in pages 347, at least, 361 of the Manuscript pursue this theme

${ }^{3}$ Lafuma 1952 introduction : 15. 
The question "What's a man within infinity?" (Qu'est-ce qu'un homme dans l'infini?) gives them their general structure. ${ }^{4}$

Pascal starts by prompting the reader to consider a mite as something very small; this serves to introduce "an entirely new kind of abyss" : pointing to the presence of not only that which is tiny all the while remaining visible, but also that which, (being so small), is invisible:

"I wish to paint not only the visible universe ... but the infinity of universes; planets; animals;

For, what is after all, Man within nature? Nothingness when compared to infinity."

This ties back to other thoughts by Pascal about science, in particular its characteristic of having to go against "common sense", or common perception.

589 B

There are other religions than Christianity.

591 B / 558 L

[A diagram of the various religions]

$592-603$ B

[Lengthy discussion of the other religions' characteristics]

604 B

The only science which goes against common perception ["le sens commun"] and the nature of Man, is the only true...

\footnotetext{
${ }^{4}$ [Their only difficulty being Pascal's use of the word 'ciron'.]
} 
605 B

The only religion which goes against nature, against common perception, is the only one to have ever been.

And, hence Christianity - defending a view of Man as faulty - being true...

"Common sense" here should not be regarded as the beliefs of common people, only, but in the very literal meaning of the human senses e.g. vision.

[It was nothing else than that very same 17 th c., Pascalian definition that Bachelard would use in his Formation of scientific mind, to define a scientific fact.]

We should put these developments, around the infinitely big and small, in the context of the scientific developments of Pascal's times.

Improvements in microscope technology had occurred during that time e.g. :

updates by "Dutch lens-makers, especially Anton von Leeuwenhoeck (1632-1723) ... allowed ... to see single blood cells circulating";

while on the front of telescopes :

“... Kepler's observations had all been done with the naked eye, but the invention of the telescope ... in the early seventeenth century allowed" 5 for observations reaching further.

Pascal goes on :

"Everything comes from nothing and tends towards infinity."

(Concluding that no one else but their "author", i.e. God, could ever understand the full picture of these events, "marvels" / "merveilles".)

${ }^{5}$ Wiesner-Hanks $2013: 296 ; 376-77$. 


\section{II - God / the "infinite being"}

Manuscript pp 3-4

"If there is a god, it is infinitely incomprehensible..."

This is the starting point for Pascal's argument :

creating what Bertrand Russell - had he read him - would have no doubt considered an interesting argument of logic, and paradox.

1. That there is no god : how could we know?

2. If there is one : by Pascal's definition (of their properties), it is outside of (our) logic.

"... infinitely incomprehensible, because, having no parts or limits, it/he/etc. ... has no relationships with us : and so we find ourselves unable to know their existence no more than their non-existence" (ibid.)

Pascal reckons he would rather be wrong in his beliefs, than be doubtful and later find out they were true all along...

"written by someone who has gone or their knees, then and now, to pray to that infinite and part-less Being" (ibid.)

[Cousin had correctly described Pascal's situation by describing his faith "hard won", and remaining "full of doubts".6]

\section{III - Connected topics : eternity, nothing-ness...}

Connected to the topic of infinity can be regarded those of eternity, and, analogous ones like nothing-ness ("rien", "neant").

\footnotetext{
${ }^{6}$ Cousin $1842: 189$.
} 
"The way humans [Men] live their lives is fully unreasonable;

take those who go through life without ever asking about the end terms of life, devoid of anxities, reflections;

letting themselves be guided by their inclinations and own pleasures [alone];

as if they could annihilate eternity by turning their thoughts away, and thinking only of their momentary happiness.

Notwithstanding, this eternity exists, and death, which shall open it [for them]..."

195 B

Thoughts of this type appear regularly in connection with Pascal's critique of entertainment ("divertissement"), which he regarded as Man's escape from misery, and simultaneously "their greatest misery"...7

Interestingly they also appear in connection with probabilities :

Manuscript p 7

"If there was an infinite amount of happy lives to win... : everywhere where there is infinity... one should not [weigh odds] ["balancer"], one must bet everything ["il faut tout donner"]"

7'Post-modernist', media philosophers either read Pascal very closely in their youths or lived in the ignorance of reliving a 17th c. moralist's ideas... 


\section{IV - More beautiful things}

"hard ... to await the arrival of such beautiful and desirable things, so go ahead and think about them, solve them"

Pascal wrote back to Fermat in a short letter from 1654; Pascal who by that time had possibly already moved on to his own problems. ['These problems are "far away" from me', "bien loin", he commented.] ${ }^{8}$

In the same way that some problems accompany mathematicians for long periods if not their entire lives, this last problem of infinity would be that of Pascal. $^{9}$

Pascal never entirely abandoned mathematics : from the study of triangles to the later mature contemplations on God, there was more continuity than breach - and more than some may find convenient.

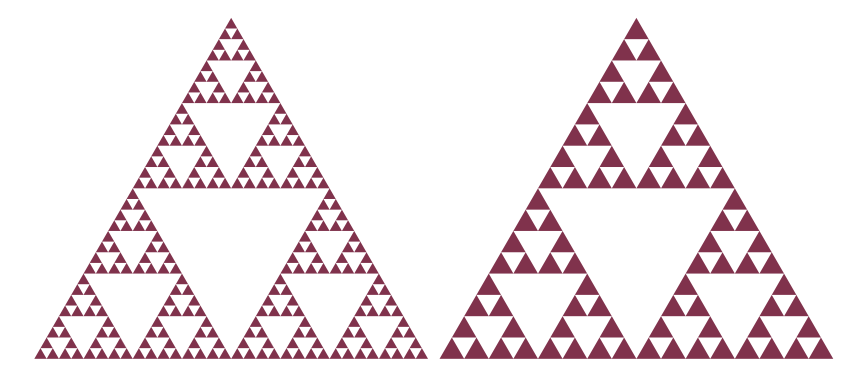

\footnotetext{
${ }^{8} 27$ th of October. A remarkably brief, polite answer to a numerical problem exposed by F.. (Possibly his last before settling in Port-Royal.)

${ }^{9}$ We think of Fermat's 'Last Theorem', or Yitang Zhang (whose life and journey in mathematics contains more philosophy than any philosophy book published in this century...)
} 
Bibliography, partial.

B : II - 44, 69, $74127,140,141,422$; infinite 128..

L : Series II 


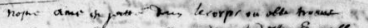

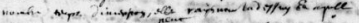

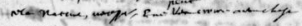

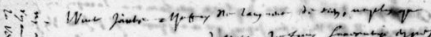

F



if



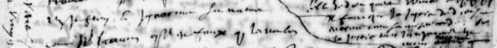

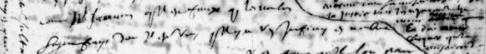

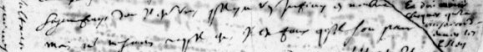

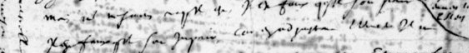



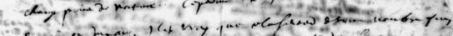

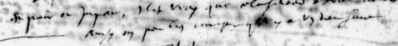

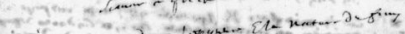

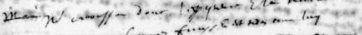

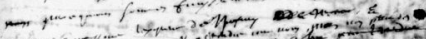



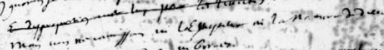

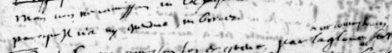

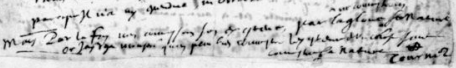

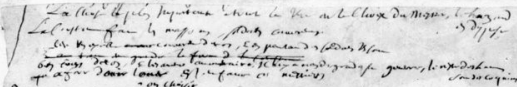

19

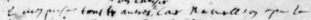

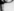

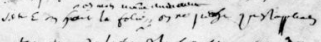

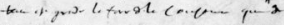

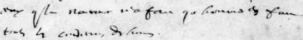

$x^{2}+1$



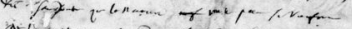



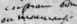




\section{RECEPTION OF PASCAL.}




\title{
Crown jewel computers : On the Schickard-Pascal "Prioritätsstreit".
}

\author{
Camille Akmut
}

April 18, 2020

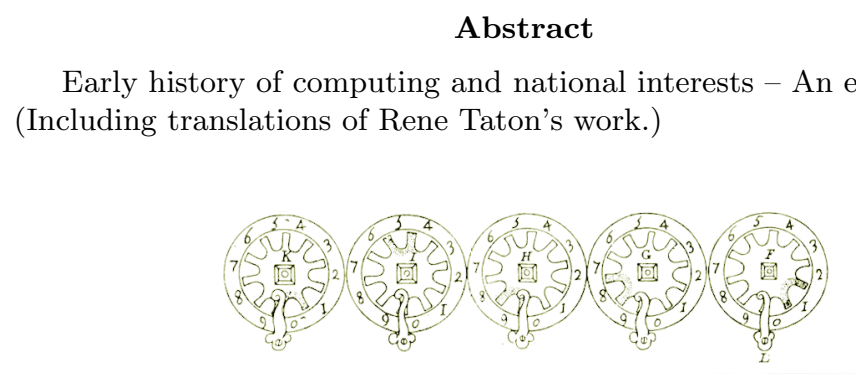


Without going as far as to say that Rene Taton's treatment of Pascal is akin to the histories given to rulers before official visits (e.g. the history of Chinese civilization and science offered to the Queen of England), his work does represent a certain state of the history of computing.

The controversies occurred at a time when Schickard's letters to Kepler had just been uncovered prompting a small revolution in historiography (late 50's).

" [Their] discovery has opened the issue of the origins of computing", Taton admitted himself.

German scholars were now declaring Shickard as the certain inventor of the first mechanical computer relegating Pascal and the Pascaline, and with it French science, to a secondary position.

" C'etait pas Pascal, mais le professeur de Tuebingen qui a invente la machine a calculs"! (trans.) ["Not Pascal but Schickard, the Professor of Tuebingen, invented the computing machine" (trans.)]

- wrote one of them.

In other words, the predecessor of the modern, electronic computer - if not its origins - had been shifted and were hitherto to be found in Germany.

What Zuse is to the 20th c. and the history of computer science, Schickard was now for the 17th and early computing history.

It is no doubt in this context that Taton's vigorous re-appreciation of Pascal in his 1963 article (translated here) should be considered; coinciding with the publication of the second edition of his treatise on early computing ${ }^{1}$.

this astronomer can not be considered the true inventor of the calculating machine

And elsewhere :

... even though soon recognized as an astronomer of some talent, his work remains of limited importance

In "On the invention of mechanical arithmetic", he still left room for error conceding that more documents may be needed.

His book Histoire du calcul offers more insights. The introduction made clear that computations (and algorithms) had now permeated the entirety of society, but the interior pages reserved Schickcard and his "' calculating clock" " a single mention while Pascal's role in history was put on full display, in all of its grandeur.

completely ignored, destroyed, Schickard's clock gave way to the additionmachine of Pascal in 1642.

And, was it not in this book - it was - that Taton went as far as putting Pascal in the same ranks as Shakespeare and Goethe... ${ }^{2}$

A triple alliance remained better than German hegemony.

How long until new letters are discovered: Russia or China, next? The history of computing would not be complete without its own history...

\footnotetext{
${ }^{1}$ Le calcul mecanique ("Que Sais-Je?", PUF)
}

${ }^{2}$ P. 7. 
"Even in a clear mind there are shadows. And, inside of us the 18th century continues to live a silent life" Bachelard wrote in one of the pages of The Formation fo the scientific mind.

Inside of these scholars, the second world war still raged on. And, perhaps the Franco-Prussian ones too.

These scholarly debates and disputes - now detached from us by the necessary historical distance (to say nothing of personal affiliations) - appear more and more as fights fought on some theoretical 'front'.

In Pascal's engineering papers we find the unmistakable marks of the scientist who conducts their science as if part of some literary salon, constantly addressing the reader with "Mon cher lecteur" - as he did. Descriptions of his Pascaline included.

Our current understanding of Pascal reveals a man greatly concerned with patents, which he did end up obtaining after some uphill battles, and money.

No pious, and world-remote thinker this Pascal!

In that way he does prefigure our modern computer scientists - Many of them carry on double employments, in academia and the private sector (sometimes simultaneously), or own investments in companies that are in conflict with what should be their neutral science. ${ }^{2}$

Financial interests are never far away from science as are national ones.

\footnotetext{
${ }^{1}$ For an English trans. : Smith's "Source book" of mathematics.

${ }^{2}$ (see our previous research)
} 
Rene Taton. 1963.

"ON THE INVENTION OF MECHANICAL ARITHMETIC"

Revue d'histoire des sciences

All the while participating brilliantly ["avec eclat"] in geometrical progress, calculus ["calcul infinitesimal"] and physics, Blaise Pascal was also the author of an innovative work in the field of applied sciences.

Due to the genius of his realizations, the care given to its implementation, and propagation efforts, his famous machine for arithmetic now strikes as one of the first examples of science applied directly to solve common problems and the point of origin of many subsequent inventions and updates - out of which the mechanical calculators or modern electronic ones emerged.

An important place must be reserved for this invention in the full oeuvre of Pascal's science.

$(\ldots)$

The history of science shows that most great discoveries emerged as the work - not of an isolated genius but a collective of researchers, and rendered possible by the entirety of progress $(\ldots)$

Certain authors were mistaken in thinking that Pascal's invention escaped this rule (...) More nuanced conclusions - taking nothing away from the creative genius of this young scientist - are reached by putting back his work inside of the global context of scientific and technical evolution [of the time].

We thought for a long time that Pascal had been the first to deal with the various questions of the mechanization of the four fundamental operations of arithmetics that are : addition, subtraction, multiplication and division. 
In fact, a recent discovery has revealed that a University of Tuebingen professor, Wilhem Schickard (1592-1635), mostly known as an astronomer during this time, had come before him.

Schickard had been appointed as professor of oriental languages at the University in 1619, but far from limiting himself to questions [and finer points] of linguistics and philology, his curiosity turned toward the exact sciences ["sciences exactes"], astronomy especially.

In 1631 he became chair of mathematics and astronomy at the same University $(\ldots)$

In contact with Kepler as early as 1617 , he then started exchanges with various well-known German, Italian, Dutch and French scholars (...)

It was in a letter from September 20th 1623 that Schikcard told Kepler of his invention for the first time, a machine featuring cogwheels [trans. note : e.g. with 'teeths'] which, he wrote, "starting from a given number is able to do computations in an instantaneous manner, addition, subtraction, multiplication and division". In a letter from February 25th 1624 he gave Kepler a somewhat precise description and provided a summary drawing. But his own exemplary of the machine had been destroyed in a fire, his later correspondence never mentioned it again.

As such, it is probable that not having understood the theoretical and practical importance of his invention, discouraged by bad luck, and drawn to other activities, Schickard had thus abandoned his research.

Kepler too seemed to have not felt the relevancy of this invention and it seems kept no recollections of it.

Schickard's letter from February was recently discovered in Pulkovo and published by F. Hammer together with some notes meant for the constructor of his machine (...) 
However, it seems to us that this can not be used to conclude any influence of Schickard on Pascal nor to consider the astronomer of Tuebingen as the real ["veritable"] creator of the arithmetic machine.

(...)

The fact that Schickard never replaced his machine is disconcerting and may point to some [deeper] technical flaws.

( ...)

As such, considering the current state of this issue, it appears legitimate to us to view Schickard as the principal precursor of mechanical computation ["calcul mecanique"], but not as the inventor of the computer / computing machine.

An invention can only be authenticated if enough witnesses of good standing ["dignes de foi"] have seen it, then was released to the world and put to use.

Such is not the case when it comes to the machine of Schickard. (...) But the adding-machine of Pascal [did fulfill all of those criteria and] influenced most of subsequent machines.

There is no doubt that Pascal's adding-machine is at the origin of the modern calculator.

\section{(..)}

The history of the theory and engineering of Pascal's adding-machine remains complicated to establish in detail. It comes to us rather only in the form of two documents : the Letter to Monseigneur le Chancelier... and Recommendation to all those who may have the curiosity to see the arithmetic machine published in 1645 .

Pascal himself points out that, from a purely theoretical point of view, it was in 1640 that he had started considering the difficult problem of the mechanization of computation.

[Trans. note : a discussion of various implementations follows, as well as 
commercial and legal aspects, and techniques e.g. subtraction by complements.] $(\ldots)$

Many inventors followed in the path thus opened. In 1672, Leibniz (...)

Sure, Schickard had demonstrated before Pascal that the operations of arithmetic could be mechanized [ / automated] and that the cogwheel [wheel with teeth] could play an essential role;

But it was Pascal who the first made clear ["precisa"] the principles of mechanical computation and illuminated the general structure of arithmetic machines, meanwhile also triumphing against the difficult technical obstacles (...)

While less brillant than first thought (...) it remains a remarkable accomplishment inside the oeuvre of one of the great representatives of 17 th century French science.

Trans. note :

Footnotes are available in the original. An appendix follows the ending. 
Rene Taton. 1961.

\section{HISTOIRE DU CALCUL.}

The modern man lives in a world of numbers. Be it commercial exchanges, income, tax or insurance, time and temperatures, the lottery or wavelengths, at every moment numbers permeate his existence. And, so, this man now regularly operates calculations not too long ago only left to the learned specialist. This vulgarization of numerical computation is the ending point of a slow evolution to which various peoples have participated since the beginning of the historical period.

Long limited to arithmetic and algebra, it took a considerable turn in the 17 th c. with the emergence of differential calculus...

(...)

A genius thinker, brilliant writer, Blaise Pascal (1623-1662) was also a talented mathematician and physicist. At 16 he put down his first discoveries in Essay pour les coniques. In 1642 he invented the first computing machine ["machine a calculer"] and, with Fermat, created (the field of) probabilities.

$(\ldots)$

computing machines, depending on their functions, take on the names of addition-, multiplying- or mixed-machines.

Following the calculating clock of Shickard (1963), soon destroyed and entirely ignored, a machine for additions was constructed by Pascal (...) Leibniz invented a multiplying-machine. (...) 


\title{
Reception of Pascal in the history of sciences...
}

\author{
Camille Akmut
}

April 27, 2020

\begin{abstract}
In particular computer science and technologies.

With references to the history of philosophy

and the social sciences.
\end{abstract}




\section{I - Crown jewel computers, and sciences}

The computer scientist Niklaus Wirth, creator of the Pascal programming language, has said of the origins of his creation :

I named it after the French philosopher and mathematician, who in 1642 designed one of the first gadgets that might truly be called a digital calculator. ${ }^{1}$

This is how Wirth remembered Pascal, and explained his choice of the philosopher for his namesake language in 1993 as part of a large conference organized by the ACM on the history of programming languages (the second HOPL);

as a pioneer in a line from which - it is either implied, or we interpret too strongly - he ultimately descended.

Another notable computer scientist, Friedrich Bauer, known for the stack ADT and his participation in the making of ALGOL $60^{2}$ among others, in his 'Historical notes on computer science' (one of his last books, if not the last) expressed the following judgment on Pascal and Schickard :

"We would not do Schickard any justice by exaggerating : his calculating machine was no 4-type ["Vier-Species"] machine, like that of Leibniz, but only a 2-type like Pascal's, but with the difference of having come twenty years earlier. Kepler was said to have been most happy with it. And, perhaps its mechanism was superior. But, that would be a detail." 3 [trans.]

Ergo : the real machine was Leibniz's - as it could (really) do all four operations of arithmetic - and as for the earlier, partial or lesser, ones Schickard's

\footnotetext{
${ }^{1}$ Found in History of programming languages, vol. 2.

${ }^{2}$ From which Wirth would draw inspiration for Pascal.

${ }^{3}$ Bauer 2009 : 67.
} 
came first and might have been even better. (One way or the other, a German inventor had precedence. $)^{4}$

We can extend this analysis to the wider history of sciences, and those of Pascal's scientific activities outside mechanical computers, by citing this study picked from many others :

"The most imaginative and influential experimental philosopher of the decades after 1650 was the Englishman Robert Boyle (...)

The so-called 'crucial' experiment whereby the brother-in law of the French mathematician, Blaise Pascal (1623-62), proved the existence of air-pressure by observing the different heights attained by a column of mercury at the bottom and top of the Puy-de-Dome, a mountain in central France, was only performed once. Pascal's purported confirmation of the experiment using the tower of the Paris church Saint-Jacques was wishful thinking: given the altitude of the building"

writes this professor from Oxford (and fellow Englishman?) ${ }^{5}$.

\section{II - Origins of a priority fight}

When looking for the beginnings of the Schickard-Pascal priority debates, we should probably look no further than the Encyclopédie.

Diderot and d'Alembert, as editors, included the Pascaline in the very first volume of their encyclopedia, under "arithmetique" ${ }^{67}$; Published in 1751 :

"The first machine for arithmetic is by Blaise Pascal, born in Clermont

\footnotetext{
${ }^{4}$ Pascal is mentioned about 15 times in this text (same-named programming language excluded).

${ }^{5}$ Brockliss 2001 : 155 .

${ }^{6}$ The sub-definition "ARITHMETIQUE (machine)" esp..

${ }^{7}$ (It takes something like the mind of a hacker to find it there. (Searching under P is useless, except maybe for 'Paschal' meaning, as it is defined there, "that which concerns the Easter of ... Christians".))
} 
in Auvergne [date]; he created it at 19. More have appeared since, which, in the opinions of the gentlemen from the Academy of Sciences themselves, appear to have advantages over it, but his [Pascal's] is the oldest ; it might have served as model for all others : hence why we have opted for it."

To give a measure of this work's importance : Pascal was now, he and his Machine, part of the most famous encyclopedia of all : "the encyclopedists had produced the most massive single reference work in Europe to date." 8

Said introduction of the machine was followed by a very lengthy and detailed description of its operation (multiple pages, in the original).

This remained the dominant view until the research and publications of Franz Hammer, Max Caspar ('Kepler's biographer'), the reconstructions by von Freytag Loringhoff... [of which enough has been said to not repeat here]

\section{III - Pascal, a programming language}

"The programming language Pascal was designed in the years 1968-

1969 ... The first compiler for Pascal was operational in early 1970"

Niklaus Wirth, creator of the programming language Pascal.

On the more sociological aspects of his choices (i.e. its pedagogic, professional dimensions), Wirth wrote :

"Pascal was born in 1969 out of an act of liberation. ... Confronted with the duty to teach programming, I had been faced with the dire

\footnotetext{
${ }^{8}$ Dewald (ed.). Vol. 2. [If descriptions like "The encyclopedists' goal was to make available to the greatest number of readers the most complete account possible of all current knowledge" sound somewhat like the Internet and Web, it's not without cause : tens of thousands of articles and hundreds of collaborators, "Parisians, provincials, and foreigners, the encyclopedists were a heterogeneous group"]
} 
options of Fortran and Algol. The former did not appeal to my taste as a scientist, the latter not to those of the practical engineer."

Its origins can however be identified as earlier :

In 1966, Wirth together with Hoare published 'A contribution to the development of ALGOL' whose abstract held

"A programming language similar in many respects to ALGOL 60, but incorporating a large number of improvements based on six years' experience with that language" 9

Wirth would later refer to this earlier work as "a direct predecessor of Pascal".

"This language is a direct predecessor of Pascal, and was the source of many features such as e.g. the while and case statements and of record structures" ${ }^{10}$

It was in that same article from 1971 that Pascal was introduced to the world, with the words :

"A programming language called Pascal is described". ${ }^{11}$

It is worth noting that nothing seems to have been included in this article on the origins of the name for this programming language. ${ }^{12}$

Wirth did not consider this an object of interest. The philosopher was obviously implied?

When did computer scientists and technologists start naming their programming languages after philosophers? Personalities? Fellow engineers, and their ancestors (e.g. Ada, derived from Pascal)?

\footnotetext{
${ }^{9}$ Wirth/Hoare 1966.

${ }^{10}$ Wirth 1971 : 123.

${ }^{11}$ Wirth $1971: 122$.

${ }^{12}$ The same goes for Algorithms... in the Pascal version (Wirth 1976), the "User manual and report" (Jensen/Wirth 1974) and Wirth 2002 so far we can tell.
} 
Bertrand is a later example following this convention.

As for the wider intellectual context in which Pascal was created, it can be found in the "structured programming" theories of Edgar Dijkstra and the work of Hoare :

Dijkstra is the very first person mentioned in Wirth's book Algorithms + Data structures = Programs (after Pascal), followed by Hoare.

Wirth himself described his programming language as "designed ... with a ... syntax representing the paradigm of structured programming" ${ }^{13}$.

In Algorithms, still, he made clear that :

"Throughout the book ... we follow the theory and terminology expounded by Hoare and realized in the programming language

PASCAL." 14

having previously cited Hoare's "Axiomatic Basis of Computer Programming" and, in this passage, "Notes of Data structuring".

\section{IV - Early social scientist (On Durkheim's reception)}

Durkheim, philosopher turned sociologist, occasionally referenced Pascal in his earlier philosophy lessons ${ }^{15}$ all the while not seeming to have much affection for him — or most philosophers, for that matter.

His philosophy is almost entirely discarded :

"With Pascal we c[ould] say that we know everything of nothing", i.e. that there is nothing that we know entirely, yet, Durkheim goes on, "this has little

\footnotetext{
${ }^{13}$ Wirth 2002

${ }^{14}$ Wirth 1976 : preface.

${ }^{15}$ About 10 mentions in a circa 300 pages text (these lectures come to us in the form of notes taken by a former student, and should thus be considered with some caution.)
} 
importance, because", according to Durkheim, "it is enough for us to know some few things to not let us be discouraged."

As for his science :

"Many ideas that seem obvious ["necessaire"] to us today were not so yesterday. Pascal did not believe in the law of gravity for instance."

His experiments with barometers are cited as an example of induction (as part of a larger expose on induction and its weaknesses).

The "amulet" is mentioned as Durkheim references Lelut's work on folly (whose study on Pascal concluded he was insane?)...

Stuart Mill is never far away from Pascal in those developments, a reference that seems to mostly serve the function of extension or "betterment" of Pascal (Mill, who, ultimately also ends up being regularly rejected).

But, was Durkheim all the more keen on distancing himself from these philosophers as he was preoccupied with founding his new science - sociology as independent from philosophy? And, all the more from Pascal as he was doing so in the specific context of his own country?

\section{V - Modern philosophy, popular culture}

Where computers and philosophy are concerned one work in particular stands out, which are the Matrix movies.

Two volumes, published in short succession, had been groundbreaking in their own way for attempting to discuss this work from the standpoint of philosophy : The Matrix and Philosophy... and Taking the Red Pill. ${ }^{16}$

Descartes was prominently featured, in too many mentions to count(!), and in fact it was with him that the first of these books began :

\footnotetext{
${ }^{16}$ Both featuring an all-star ensemble of various writers, computer scientists, transhumanist experts, futurists, media philosophers, and such.
} 
... immediately saw the connections between the film and Descartes's speculations on the possibility of deception by dreams or an evil deceiver.

This introduction even asked : "Is this a Christian film?".

While the second had for full title 'Science, Philosophy and Religion'...

And, yet Pascal was nowhere to be found :

Neither in one nor the other; Pascal who shared many of the same characteristics as Descartes (being a philosopher-mathematician ${ }^{17}$ ), had questioned infinity, discussed truth vs. false perceptions, and even thinking machines!

This absence is worth noting all the more as in books that otherwise were not lacking in, various, references.

Either imputable to the quality, 'caliber' of commentators; or the insufficiency even insignificance of Pascal.

(We leave this judgement to others.)

\section{VI - Cousin's interpretation}

Because the philosopher Victor Cousin played such an important role in our current understanding of Pascal, having produced the first scientific edition of the Pensees, (or what this author considers to be so), here his assessment of the differentiated legacies of Pascal :

Descartes, who constantly invents and creates, sometimes makes errors. Pascal does not possess the same unbounded creativity ; however what does come out of him is always exquisite and complete ["acheve"]. Let us be honest : in Pascal, the Man is profoundly original, but the creative mind had not been given to him. In mathematics,

\footnotetext{
17 "Or, Pascal et Descartes ce sont deux geometres et deux philosophes" as Cousin noted (report p. 4) ["Descartes and Pascal : ... two geometers and philosophers.]
} 
he has not made any of the sort of discoveries that change the face of science, such as the application of algebra to geometry : the only big mathematical computation ["calcul"] that remains associated with him is that probability; and this he shares at least on same standing with Fermat. In physics, he demonstrated the gravity of air which Descartes had found twelve years before even Toricelli. In philosophy he did little but reactivate the old battle of faith against reason. (...) [Pascal] has put nothing new into the world, but what he touched he brought to supreme perfection. (Report, p. 6)

1. Computers, and programming languages.

2. 'Philosopher-mathematician' before Bachelard (whose doctoral advisor was no other than Brunschvicg), Cavailles, and the others;

3. Origin point with Descartes of a long line of philosophers, and soon-to-be ex philosophers, who mixed philosophy with various scientific disciplines resulting in often stark results... E.g. sociology, linguistics...

These were some of the many sides of Pascal's legacy, in the various sciences, including the social sciences; and beyond.

If Lenin accused one of his opponents of "worming his way into debates, without opinion", the same cannot be said of our scholars.

And, yet in some cases we get strong indications that not always merely the noble search for truth may guide them. 


\section{Bibliography, partial}

Hammer, Franz. 1958. "Nicht Pascal, sondern der Tubinger Professor Wilhelm

Schickard erfand die Rechenmaschine" Bueromarkt 13 : 1023-25.

Caspar, Max. 1958. Johannes Kepler. Kohlhammer verlag. 3rd. ed..

(Republished just in time for the "Streit")

Lenin, V.. State and revolution.

[It was here I believe that Lenin also noted how after the death of Marx, flip-

flopping German scholars suddenly rediscovered their dear 'national' Karl...]

\section{Pascal (the programming language)}

- Wirth, Niklaus and Hoare C. A. R.. 1966. "A Contribution to the Development of ALGOL". Communications of the ACM 9(6) : 413-432.

-Wirth, Niklaus. 1971. "The Programming Language Pascal". Acta Informatica $1(1): 35-63$.

- - 1976. Algorithms + data structures $=$ programs. Prentice-Hall.

(This edition uses Pascal, later ones its successors.)

•- . [1993]. "Recollections about the development of Pascal". ACM SIGPLAN

'HOPL-II' conference. In : Bergin/Gibson 1996.

•- . 2002. "Pascal and its Successors". http://www.swissdelphicenter.ch/en/niklauswirth.php

- Jensen, Kathleen and Wirth, Niklaus. 1974. PASCAL. User manual and report.

Lecture notes in computer science. Springer.

(This contains more bibliography.)

- Bergin/Gibson (eds). 1996. History of Programming Languages II. ACM Press.

(The first volume is of lesser interest, contains ALGOL 60 discussions.) 


\section{0}

A R I

gleterre 870000 , \& dans les villages \& hameaux 4100000 . Il eftime la rente annuelle des terres à ro millions fterlin; celle des maifons \& des bâtimens à deux millions par an; le produit de toutes fortes de grains, dans une année paffablement abondante, à 9075000 liv. At. la rente annuelle des terres en blé, à 2 millions, \& leur produit net au-deffus de 9 millions fterlin; la rente des pâturages, des prairies, des bois, des forêts, des dunes, $\mathcal{E} c$. à 7 millions fterlin ; le produit annuel des beftiaux en beurre, fromage \& lait, peut monter, felon lui, à environ $2 \frac{r}{2}$ millions fterlin. Il eftime la valeur de la laine tondue annucllement à environ 2 millions fterlin: celle des chevaux qu'on éleve tous les ans à environ 250000 liv. Aterlin; la confommation annuelle de viande pour nourriture, à environ 3350000 liv. Atcrlin : celle du fuif \& des cuirs environ 600000 livres fterlin: celle du foin pour la nourriture annuelle des chevaux, environ 1300000 livres fterlin, \& pour celle des autres beftiaux, un million fterlin : le bois de bâtiment coupe annuellement, 50000o liv fterl. Le bois à brûler, Ec environ g0000o liv. Aterl. Si toutes les terres d'Angleterre étoient également diftribućes parmi tous les habitans, chacun auroit pour fa part environ $7 \frac{1}{4}$ arpens. La valeur du froment, du feigle, \& de l'orge néceffaire pour la fubfiftance de l'Angleterre, fe monte au moins à 6 millions fterl. par an. La valeur des manufactures de laine travaillćes en Angleterre, eft d'environ 8 millions par an; \& toutes les marchandifes de laine qui fortent annuellement de l'Angleterre, paffent la valeur de 2 millions fterl. Le revenu annuel de l'Angleterre, fur quoi tous les habitans fe nourriffent \& s'entretiennent, \& payent tous les impôts $\&$ taxes, fe monte, felon lui à environ 43 millions: celui de la France à 8 I millions, \& celui de la Hollande à 18250000 livres fterlin.

- Le major Grant, dans fes obfervations fur les lifees mortuaires, compte quil y a en Angleterre 39000 milles quarrés de terre: quil y a en Angleterre \& dans la principauté de Galles, 4600000 ames : que les habitans de la ville de Londres font à peu près au nombre de 640000 ; c'eft - à-dirc, la quatorzieme partie de tous les habitans de l'Angleterre: qu'il y a enAngleterre \& dans le pays de Galles, environ 10000 paroiffes: qu'il y a 25 millions d'arpens de terre en Angleterre \& dans le pays de Galles, c'eft-à-dire, environ 4 arpens pour chaque habitant: que de $100 \mathrm{en}$ fans qui naiffent, il n'y en a que 64 qui attcignent l'âge de 6 ans; que dans 100 , il n'en refte que $40 \mathrm{en}$ vie au bout de 16 ans; que dans 100 , il n'y en a que 25 qui paffent l'âge de 26 ans; que 16 qui vivent 36 ans accomplis, \& 10 feulement dans roo vivent jufqu'à la fin de leur $46^{\mathbf{e}}$ année; $\&$ dans le même nom bre, qu'il n'y en a que 6 qui aillent à 56 ats accomplis ; que 3 dans 100 qui attcignent la fin de 66 ans; \& que dans 100 , il n'y en a qu'un qui foit en vie au bout de 76 ans: \& que les habitans de la ville de Londres font changés deux fois dans le cours d'environ $6_{4}$ ans. Voyez VIE, Ec. MM. de Moivre, Bernoulli, de Montmort, \& de Parcieux, fe font exercés fur des fujets relatifs à l'Arithmétique politique : on pelt confulter la doctrine des hafards, de M. de Moivre; l'art de conjecturer, de M. Bernoulli; l'analy fe des jeux de hafard, de M. de Montmort ; l'ouvrage fur les rentes viageres E les tontines, \&c. de M. de Parcieux ; \& quelques mémoires de M. Halley, répandus dans les Tranfactions philofophiques, avec les articles de notre Dictionnaire, HASARD, JEU, PROBABILITÉ, COMbiNAISON, ABSENT, Vie, MORT, NAISSANGE, Annuité, Rente, Tontine, E'c.

Arithimétioue, pris adjectivement, fe dit de tout ce qui a rapport aux nombres, on à la fcience des nombres, ou qui s'exécute par le moyen des nombres. On dit opération arishańsique, de toute opération fur les nombres.
A R I

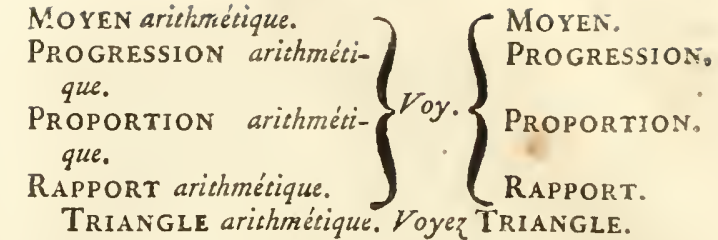

ECHELles ARithímítiques, eft le nom que donne M. de Buffon (Mém. Acad. z J42.) aux différentes progreffions de nombres, fuivant lefquelles l'Arithmétique auroit pû être formée. Pour entendre ceci, il faut obferver que notre Arithmétique ordinaire s'exécute par le moyen de dix chiffres, \& qu'elle a par conféquent pour bafe la progreffion arichmétique décuple ou dénaire, $0,1,2,3,4,5,6,7$, 8,9 , Voyez Progression, Ec. Il eft vraiffemblable, comme nous l'avous remarqué plus hant, que cette progreffion doit fon origine au nombre des doigts des deux mains, par lefquels on a dû naturellement commencer à compter: mais il eft vifible auffi que cette progreffion en elle-même eft arbitraire, \& qu'au lieu de prendre dix caracteres pour exprimer tous les nombres poffibles, on auroit pû en prendre moins ou plus de dix. Suppofons, par exemple, qu'on en eût pris cinq feulement, $0,1,2,3,4$, en ce cas tout nombre pafié cinq, auroit eu plus d'un chiffre, \& cinq auroit été exprimé par 10 ; car I dans la feconde place, qui dans la progreffion ordinaire, vaut dix fois plus qu'à la premiere place, ne vaudroit dans la progreffion quintuple, que cinq fois plus. De même i I auroit repréfenté $6 ; 25$ auroit été repréfenté par 100, \& tout nombre au-deffus de 25 , auroit eu trois chiffres ou davantage. Au contraire fi on prenoit vingt chiffres ou caracteres pour repréfenter les nombres, tout nombre au-defious de 20 , n'auroit qu'un chiffre; tout nombre au-deffous de 400 , n'en auroit que deux, Ecc.

La progreffion la plus courte dont on puiffe fe fervir pour exprimer les nombres, eft celle qui eft compofée de deux chiffres feulement $0,1, \&$ c'eft ce que M. Leibnitz a nommé Arithmétique binaire. Voy BinaIre. Cette Arithmétique auroit l'inconvénient d'employer un trop grand nombre de chiffres pour exprimer des nombres affez petits, \& il eft évident que cet inconvénient aura d'autant plus licu, que la progreffion qui fervira de bafe à l'Arithmétique, aura moins de chiffres. D'un autre côté fi on employoit un trop grand nombre de chiffres pour l'Arichmétique, par exemple, vingt ou trente chiffres au lieu de dix, les opérations fur les nombres deviendroient trop difficiles; je n'en veux pour exemple que l'addition. Il y a donc un milieu à garder ici; \& la progreffion décuple, outre fon origine qui ct affez naturelle, paroît tenir ce milieu : cependant il ne faut pas croire que l'inconvénient fût fort grand, fi on avoit pris neuf ou douze chiffres aulieu de dix. Voyez CHIFrRe \& Nombre.

$M$. de Buffon, dans le Mémoire que nous avons cité, donne une méthode fort fimple \& fort abregée pour trouver tout d'un coup la maniere d'écrire un nombre donné dans une échelle arithmétique quelconque, c'eft-d̀-dire en fuppofant qu'on fe ferve d'un nombre quelconque de chiffres pour exprimer les nombres. Voyez Binaire. (O)

*ARith métique (machine), c'eft un affemblage ou fyrtème de roues \& d'autres pieces, à l'aide derquelles des chiffres ou imprimés ou gravés fe mellvent, \& exécutent dans leur mouvement les principales regles de l'Arithmétique.

La premiere machine arithmérique qui ait paru, eft de Blaife Pafcal, né à Clermont en Auvergne le 19 Juin 1623 ; il l'inventa à l'âge de dix-neuf ans. On en a fait quelques autres depuis qui, au jugement même de MM. de l'Académie des Sciences, paroiffent avoir fur celle de Pafcal des avantages dans la pratique: 
Figure 1: The Matrix

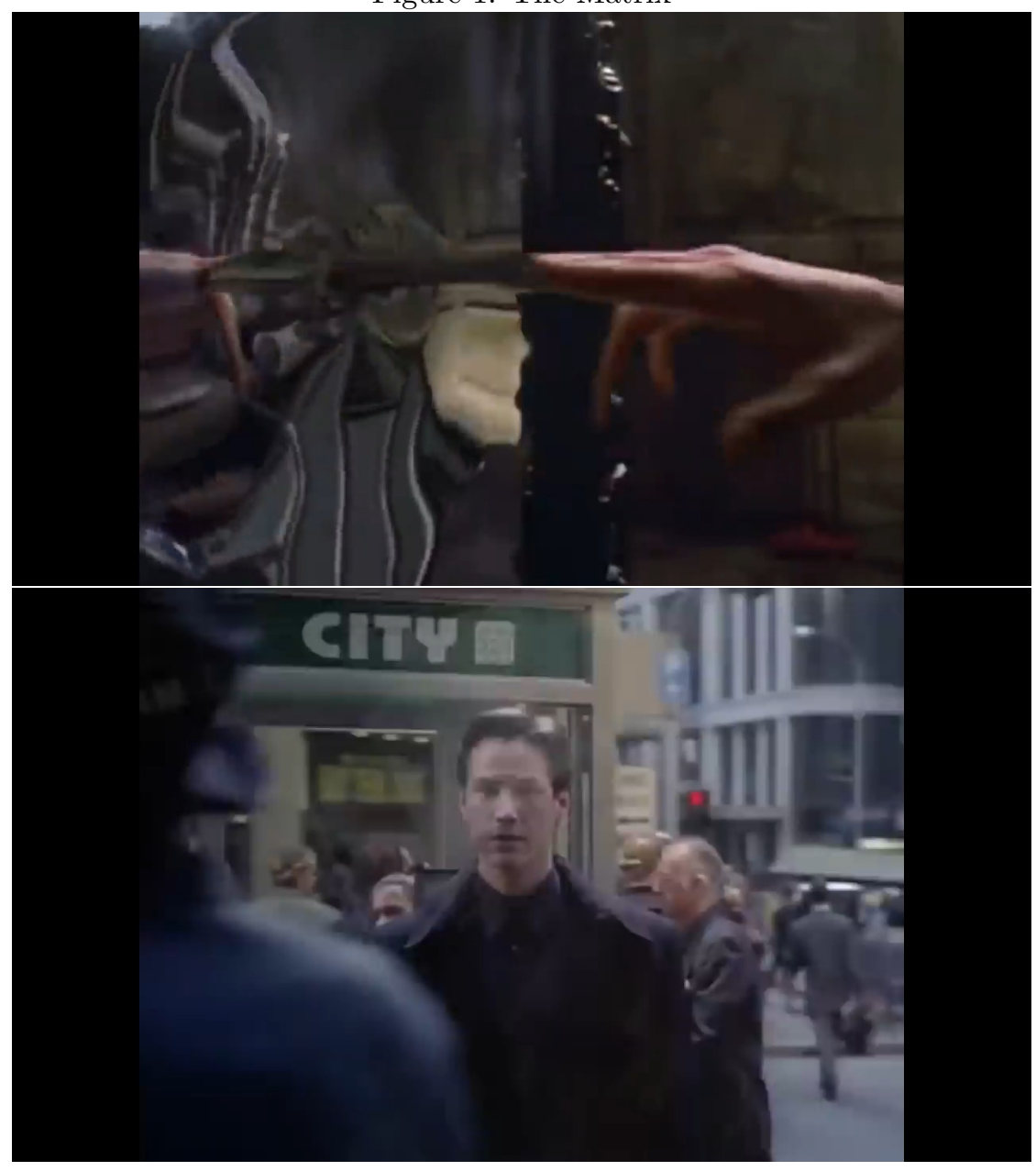

"Spirit has a natural tendency towards believing, and will loves naturally; such that, being deprived of real objects, they attach themselves to false ones."

(Pascal, Pensees $81 \mathrm{~B}$ ) 


\title{
Russell and Nietzsche contra Pascal : a famous and partial 'History of philosophy'.
}

Camille Akmut

May 3, 2020

\begin{abstract}
Bertrand Russell had little love for Pascal - this should be no secret : In A History of Western Philosophy, Nietzsche became the 'anti-Pascal'. A role too perfect for Nietzsche whose relationships with the latter were complex ("I don't read Pascal, I love him...", a regular companion).
\end{abstract}




\section{Introduction}

From strange affection, to open strong dislike : such are some of the extremes of the reception of Pascal, who seems to rarely leave anyone cold who reads him.

And, then there is total dismissal yet...

In our context, i.e. the sociology of computer science and technology, Russell plays an important role in the history of Pascal's reception :

This distinguished logician met the creator of 'computers'-turned philosopher with much disapproval; as an unwanted, and denied ancestor.

\section{I - A 'History of philosophy' jumps over a philosopher...}

Perhaps the most famous ignorance of Pascal is Russell's.

In his book, the popular A History of Western Philosophy there was no place for him : between Descartes and Leibniz, only Spinoza and no one else!

(The table of contents is particularly informative in this regard.)

\section{MODERN PHILOSOPHY}

\section{Part I}

From the Renaissance to Hume

$\begin{array}{ll}\text { I General Characteristics } & 511 \\ \text { II The Italian Renaissance } & 516 \\ \text { III Machiavelli } & 525 \\ \text { IV Erasmus and More } & 533 \\ \text { V The Reformation and Counter-Reformation } & 544 \\ \text { VI The Rise of Science } & 547 \\ \text { VII Francis Bacon } & 563 \\ \text { VIII. Hobbes's Leviathan } & 568 \\ \text { IX Descartes } & 580 \\ \text { X Spinoza } & 592 \\ \text { XI Leibniz } & 604\end{array}$

Pascal had never been.

To Leibniz Russell had dedicated a monograph in his younger years; 
Descartes is welcome with open arms :

"Descartes is usually considered the founder of modern philosophy, and, I think, rightly" — Russell commented.

Yet Pascal had not been entirely erased from this history of philosophy :

He appears in four places, in chapters other than his (non-existent) own;

Of which the following is the most open in terms of Russell's own assessment :

"It must be admitted that there is a certain type of Christian ethic to which Nietzsche's strictures can be justly applied. Pascal and Dostoevsky-his own illustrations-have both something abject in their virtue. Pascal sacrificed his magnificent mathematical intellect to his God, thereby attributing to Him a barbarity which was a cosmic enlargement of Pascal's morbid mental tortures. ..."

Pascal : rejected, because he resembled them so, and abandoned them so.

\section{II - Nietzsche : contra, and with Pascal?}

It would be coming closer to the truth to say that the habitual relationships between Nietzsche and, the dead, Pascal were ones of intellectual exchange :

Nietzsche found useful material in Pascal's work, based on which he expounded his own, analogous, ideas.

"The Man of science is quite the paradox (...)

It would be doing the great mass of scholars a great $[\mathrm{er}]$ honor to view them as peasants/farmers ["Ackerbauer"] (...)

Pascal said that people go about their business, and their science eagerly in order to avoid the questions that solitude would otherwise 
raise in them, which is to say the [big, old ones] : Where From? How?

And, for what Purpose?

But, even more surprising is that the very next questions they should be asking aren't [asked], this is to say : Why all this work? Why the urgency? The giddiness, the frenzy? Is it perhaps to pay [rent and such] ["Broderwerb"]?"

In fact Nietzsche seemed to have found this particular thought of Pascal so inspiring that it can be found both in his notes ${ }^{1}$, and his published work, the first part of Unzeitgemässe Betrachtungen ${ }^{2}$, in re-worked form.

Five years later, Pascal was still on Nietzsche's mind : his thoughts on the "two (kinds of) minds" were this time an object of preoccupation. ${ }^{3}$

Note Nietzsche is translating from the 'Pensees', which he rarely mentions explicitly, so we do it for him here.

Yet there were the more critical passages too, of course :

In particular Morgenröthe / Dawn was full of Pascal references (being itself a collection of 'thoughts' on moralism, its prejudices)...

"Doubt of doubt. "What marvelous pillow doubt is to a solid mind!"

This Montaigne [quote] had always [irratated] Pascal, who more than anyone had needed a good pillow."

(Morgenröthe, 46)

"Christianity has the instincts of a hunter when it comes to all those who - somehow - may be brought to despair. Behind them it always hides, and waits." [Pascal as an example]

\footnotetext{
${ }^{1}$ Nachgelassene Fragmente, 28, 1873, p. 613.

${ }^{2}$ P. 203.

${ }^{3}$ Cf. Nachgelassene Fragmente..., 36, 1878, p. 572.
} 
(Morgenröthe 65)

In 79, Nietzsche (again without citing the Pensees) refers to Pascal's thought on the "shameful I".

And, finally there's the passage from 'Why I'm so smart' where Nietzsche in a way sums up his ambivalent attitudes towards Pascal :

"I don't just read Pascal, I LOVE him... as the greatest [most informative] victim of Christianity. [killed slowly, first physically, then psychologically]"

(Ecce Homo, p. 285)

\section{III - An uncertain Nietzsche "quote"}

From the History of Western Philosophy, still :

"a very eloquent passage about Pascal (...) deserves quotation, because it shows Nietzsche's objections to Christianity at their best: "What is it that we combat in Christianity? (...): that gruesome way of perishing, of which Pascal is the most famous example."” The aristocratic B. Russell does not cite a source for this Nietzscheattributed writing;

We can speculate, but not for long : (Did Russell read German?) Was this a translation of his own?

Its unfortunate origin seems to have been for Russell the highly controversial, partly contested so-called 'Will to Power' volume - as it is known in English - whose Ludovici translation (this other aristocrat of the melancholic kind) corresponds word for word to that rendered here. ${ }^{1}$

\footnotetext{
${ }^{1}$ Note there is a similar, but diverging, passage in Der Antichrist however. (right at the beginning)
} 


\section{Bibliography, partial}

- Nietzsche. Werke. Many vol.. Colli et al.

_" "The Will To Power"". Trans. Ludovici. In : Levy (ed.) Complete works 


\section{SELF-CRITIQUE}

BEING ALSO CRITIQUE. 


\title{
Critique, and self-critique.
}

\author{
Camille Akmut
}

May 16, 2020

\begin{abstract}
Were there really "two Pascal's"? If there was a worldly period, how long did it last? And, was the separation between mundane and contemplative lives as strict as proposed?
\end{abstract}




\section{Pascal's attributed poetry}

Regarding our assertions of a "happy, go lucky" teenage Pascal :

A document called "Paroles pour un air", with the specific sense of being lyrics ("paroles") for a song ("air", or tune), is known to us;

In which a young Pascal (already) reflects stark themes of death and unhapiness in the context of poetry on love :

"I

Reduced to the last day of a dying existence ["vie."]

II

What good does it do me to think of my past sadness

Le us die ... without resistance

... it's enough,

The editors of this text indicate it must have been composed "in the period that preceeded their departure for Rouen" ("naturally").

If correct, this would have made him around 18 by then (an age were professonal life did start in the 17th c. too).

This is in addition to the specific context of said text being a generic writing i.e. one following rules, constraints of its genre.

[When we said that Pascal strived, this was meant to describe education; a child's happiness is not made of such matters only.

${ }^{2}$ Brunschvicg/Boutroux 1923 : 240-241.

3

Gilberte gave an indication that because her father was so concerned with Pascal's intellectual advancement that he overlooked health.] 


\section{A modern language}

Cousin had insisted at length on just how much Pascal's language represented a major innovation when compared with that of his contemporaries or predecessors.

${ }^{13}$ The buffoneries of these nobles have been rendered plainly even in respectable history textbooks : [in Louis XIV's court] "nobles vied with each other to ... bring breakfast" [to the King], "handing napkins" [to said king] and "emptying the royal chamber-pot" Europe, Cambridge Univ. Press, p. 283 (Early Modern

${ }^{14}$ Encyclopedia of the Early Modern world. Entry : "Arnauld Family"

In his defense of a new for a new edition in front of the French Academy, this topic occupies multiple pages.

"Descartes created it [French prose], Pascal fixed it"15

is arguably one of the most notable passages from this presentation.

Here "fix" must be understood as making permanent, or stable.

Pascal hated (or specifically avoid) pomp, yet the Port-Royal editors adapted his language "in hundreds of places". ${ }^{16}$

(Descartes had picked Latin for)

(he was retired, but his language was very much part of the (new) world.) 


\section{The issue of the 1662 patents}

In 1662 , more patent requests were received by Pascal.

"Lettres-patentes pour l'entreprise des carrosses à cinq sols (janv.mars)." 17

Had Pascal, just before his death, come home, and found his old ways back?

Or had he -on the contrary- never abandoned them, and there was never a breach, and Mother Angelique was right?;

This idea that no miracle could be expected from someone like him.

If this is deemed something worth pursuing, note :

Following Pascal's death, the "Discours sur les Pensees" (preceding the Port-Royal edition?) sang his praises, "a large spirit", etc. etc..

(plus the various notary acts)

${ }^{15}$ C. P. 4.

${ }^{16}$ Cousin $1842: 89$. ["Pascal hait les mots d'enflures", cent examples"]
${ }^{17}$ Taton 1962. (chronology) 


\section{Atheism, 16th - 18th c.}

While not turning back on our assertion that "much of intellectual activity in the West" consisted in just the kind of activities undertaken by Pascal (before, during and shortly after his times), i.e. the discussion, endorsement or otherwise legitimization of Christianity :

(And elsewhere, and synchronously, other religions)

Atheism, or unbelief, was a possibility!

Rabelais (c. 1494-1553), Vanini (1585-1619), Hobbes (1588-1679), Spinoza (1632-1677), de La Mettrie (1709-1751), Diderot (1713-1784), baron d'Holbach $(1723-1789)^{18}$

- to cite only prominent figures, usally remembered by history; and behind whom almost-always hides a long list of people.

[Cousin also noted how all previous editions has weakened Pascal's skepticism through (their) alterations. (176)]

\footnotetext{
${ }^{18}$ List established from Dewald. See also Febvre's The Problem of Unbelief ... Religion of
Rabelais.
} 


\section{* - Notes on the sociology of the Pascal family}

The sociological truth of the Pascal family is obtained from their circle, esp. the company kept by their father: Fermat (not noble...), Mersenne (certainly not noble), Roberval (yet another peasant's son!*) etc. etc..

[*"de Roverval", opposite of being mark of nobility, simply describes the village $^{1}$ in which he was born]

Blaise did not attend university, did not obtain any degrees, let alone relevant ones (law) - which would have been a likely requirement to follow in Etienne's footsteps :

Hence the only son did not pursue the career-position of his father. The father sold it. Then fled. Jacqueline joined the religious professions, while Blaise lived the existence of a quasi-churchman...

In the 20th and 21st centuries, they bought hotels, golf courses, ferraris and tigers... :

In the 17 th century, they might have bought positions with associated nobility titles;

'Small' nobles or 'grand' bourgeois? "Small" nobility or "grande" bourgeoisie? This "nobibility" has more in common with the rich of today,

${ }^{1}$ This is how Condorcet refers to it (in Roberval's eloge).

Called to government service as a means of improving the social standing of his family, the bourgeois son was an agent of upward social mobility. Officeholding became an important avenue of ennoble- ment, as certain offices conferred nobility instantly and others conferred it over the course of three generations." (Crown and Nobility in Early Modern France, p. 9)

These were the backgrounds of Etienne Pascal, and the bourgeois origins of the Pascal family. - so far as we can tell.

"Those wealthy and/or talented nobles who made a brilliant career in the state now had more in common with commoners who rose to prominence in and through the state than with fellow nobles"

Zmora writes in the context of robe nobilities. (Zmora 2001 : epilogue.)

Bohanan, Donna. 2001. Crown and Nobility in Early Modern France. Palgrave.

Zmora, Hillay. 2001. Monarchy, Aristocracy, and the State in Europe, 13001800. Routledge. 


\section{Conclusion}

"I've made a choice".

This theme is an old Christian one found prominently in the opening of Dante's Divine Comedy :

Following the temple of philosophers, the first in hell are those who did not make a choice; and thus are "condemened to follow a banner for eternity".

In the philosophy lessons of Durkheim, a quote attributed to Pascal is found reflecting similarly :

"One cannot entertain two big passions at the same time."

Pascal had made a choice : He had ceased looking away. 
“... Mother Angelique [of Port-Royal] thus judged Pascal : she said how "there was no reason to expect a miracle coming from a person such as him." "7

On making choices : MS, beginning, close to the writings on infinity.

\section{Note}

(In the above,) We use the convention of reserving italics for texts by Pascal, his family or wider circle; to enable easy access to them. 


\title{
Endless world of Blaise Pascal : a working bibliography.
}

\author{
Camille Akmut
}

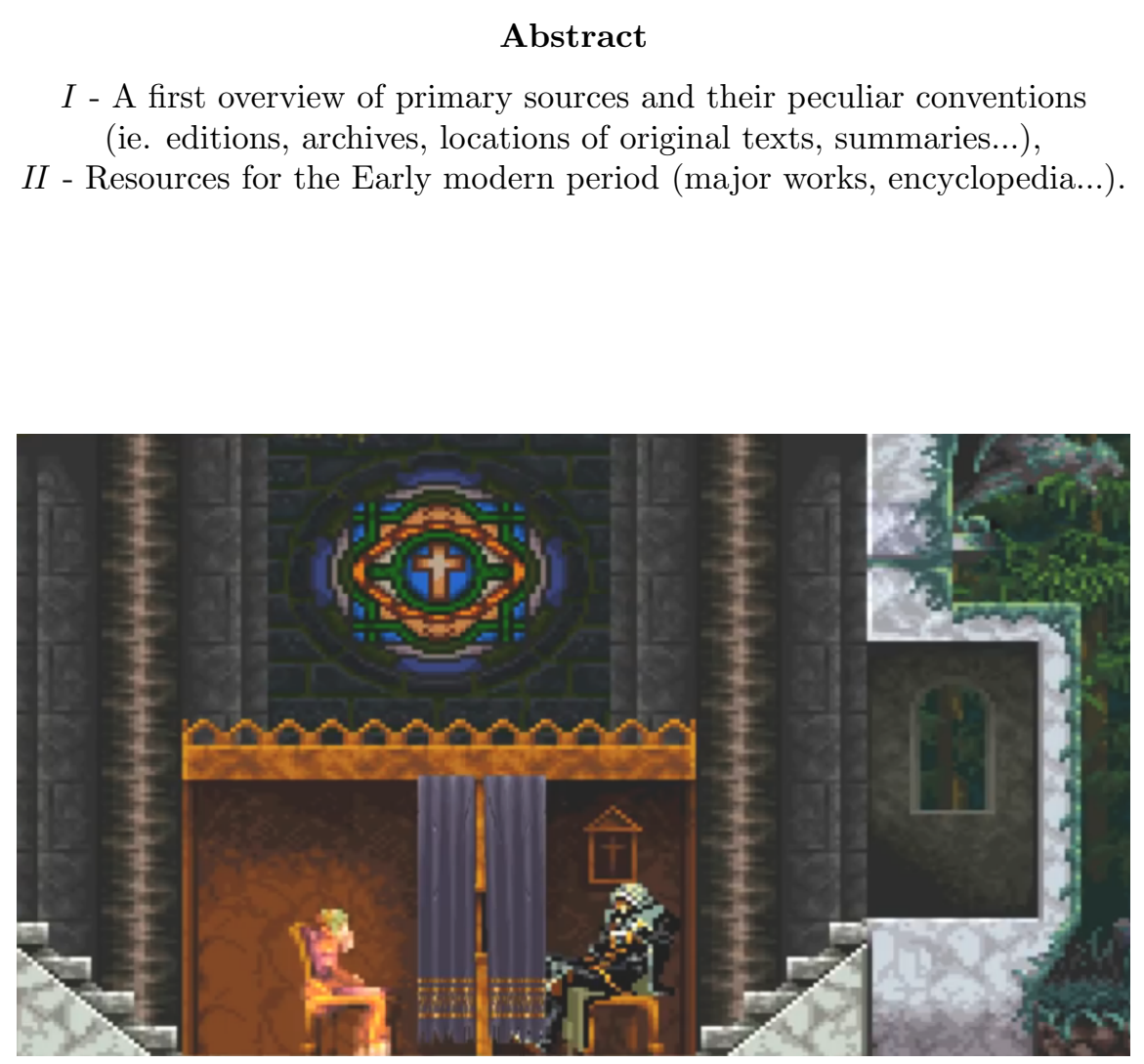


Unless otherwise noted ${ }^{\mathrm{x}}$ all translations were ours. They come principally from older and modern French, and German (forcefully Latin).

\section{Primary sources}

Pascal, Blaise.

- 1640. "Essay sur les coniques". [Early mathematics paper] e.g. Brunschvicg/Boutroux 1923 : c. 260.

- "Advis. Necessaire a ceux"... / 'Notice. Useful to those who will wish to see the Machine for arithmetic, and to use it'. [Description-advertisement]

- (attr.). "Paroles pour un air". [Poetry]

- (to). 1649. Privilege. [Patent for the arithmetic machine]

e.g. Brunschvicg/Boutroux 1925 : 401 ff.; Brunschvicg 1904 : 340 (partial?)

- 1651. [Temp. title: Jacqueline's inheritance].

e.g. Brunschvicg/Boutroux 1925 : 565 ff.

(Another one of those events that highlighted certain qualities existing within Pascal, and that may have contributed to his conversion. NB 1651, death of their father)

- (attr.). c. 1653. Discours sur les Passions de l'Amour / 'Discourse on the passions of Love'.

e.g. Brunschvicg/Boutroux vol $3: 119 \mathrm{ff}$.

(Discussion of attribution divided into 'external', ie. sources/archives, and 'internal' criteria, ie. could Pascal have written such a text : c. 114-15.)

- 1654. ['Memorial' ('amulet')]. 
- Cousin, Victor. 1844. Des Pensees de Pascal. Lib. phil. Ladrange.

(Begins with the Report; Pensees based on the Manuscript in appendix.)

- Faugere, Prosper (ed.). 1844. Pensees... Andrieux.

Vol. 1 : introduction, letters...; Vol. 2 : Pensees.

(In the introduction Faugere credits Cousin of "having made disappear, without replacing it one of the great books"...)

- Brunschvicg, Leon (ed.). 1904. Oeuvres de Blaise Pascal. Pensees. T. 1-3. Hachette.

The 'thematical' edition : here the fragments were organized around themes; also called 'subjective'.

(Not very useful for research, ie. no conclusions regarding order or structure should be made based on this, but possibly the most widely available version, being out of copyright?, so for now it can't be bad practice to provide references.)

- Lafuma, Louis (ed.). 1952. Pensees. 3 vol.. Ed. Luxembourg.

After Cousin the next biggest innovation in the edition of the Pensees : based on Copy 1, rather than the manuscript.

(Vol. 1 : Pensees based on $\mathrm{C}_{1}$; Vol. 2 : notes; Vol. 3, first part : mostly the usual biographies of Pascal...)

Section II : the unnumbered fragments

section III : the fragments not present in $\mathrm{C} 1$ but found elsewhere (e.g. Manuscript). [Newer editions have tried to establish an original ('objective') order but not based on that of the Manuscript, but this time on (two) existing copies, $\left(\mathrm{C}_{1}\right.$ and $\mathrm{C}_{2}$ ), some emphasise one over the other, including Lafuma, and Sellier...] 


Useful for making sense of some of the sources
P-R, or variants thereof : Port-Royal (edition)
B : Brunschvicg or Bossut (depending on period / context)
MsC : Manuscript
[e.g. Lafuma uses RO, "receuil original", for this
(hence whenever a mention of "original lost" appears in his tables,
a star, *, is also found under RO) ]
Archives
Manuscript : 9202
Copy $1: 9203$
Copy 2 : 12449
BN = Bibliotheque Nationale (prev. the "Royal Library") Fr $=$
(Fonds) francais

* Arnauld/Nicole(/Pascal...). Logique de Port-Royal / 'Port-Royal Logic'. (Probably the most underestimated and fascinating text of this century.)

* Filleau de la Chaise(?). Discours sur les Pensees.

Presumed summary of talk given by Pascal about his project for the Pensees. (Dubois / Du Bois ...)

* Pascal, Etienne and Roberval. 1636. ['To Fermat']. [Mathematics paper (a letter)]

e.g. Brunschvicg/Boutroux 1923 : 169 and surrounding.

* Pascal, Jacqueline. 1657. Reglement pour les enfants / 'Rules to serve in the government of children'. 
—. 1655. Letter to Pascal from January 19th. [Temp. title : 'Solitary happiness rather than wordly one']

e.g. Brunschvicg/Boutroux vol $7: 83 \mathrm{ff}$.

* Perier (nee Pascal), Gilberte. Vie de (Blaise) Pascal / 'Life of (Blaise) Pascal'.

* Perier, Etienne. 1670. Preface / 'Preface' to the Pensees.

* Perier, Marguerite. ['Memoir'].

* Racine, Jean. Abrege de l'histoire de Port-Royal / 'Port-Royal, a short history'.

* Diderot / d'Alembert (eds). Encyclopedie. Many vol..

(In particular "arithmetique".)

* Jansen. Augustinus...

* Augustine

(De doctrina Christiana and City of God are referenced in Pensees) 
- Cousin, Victor. 1842. Rapport a l'Academie francaise... / 'Report to the French Academy on the need for a new edition of Pascal's Pensees'. In : Cousin 1844 .

(Critique of the Port-Royal edition from 1669 and the 1779 Bossut edition, until then dominant.)

4-8: Descartes vs. Pascal
9-10: major issues (with the ed. of 'Pensees')
$11-18$ : what sources exist
$18-19$ : structure of the report
20 - First part -
$23:$ what C. understands as being part of P.
$25 \mathrm{ff}:$ critique of Bossut's edition
$47 \mathrm{ff}:$ critique of Port-Royal's edition
$69:$ conclusion/summary
72 - Second part -
$88:$ details the various kinds of P-R alterations
$90-91$ : those "fortunate", "necessary" ones
$92:$ useless corrections
$102:$ really bad ones (additions)
$105:$ really bad ones (suppressions)
$113:$ major revisions
(this should make it easier to start working on this)

- Brunschvicg, Leon and Boutroux, Pierre later Glazier (eds). Various years. Oeuvres de Blaise Pascal... [“... in chronological order ..."]. Many vol.. Hachette. 


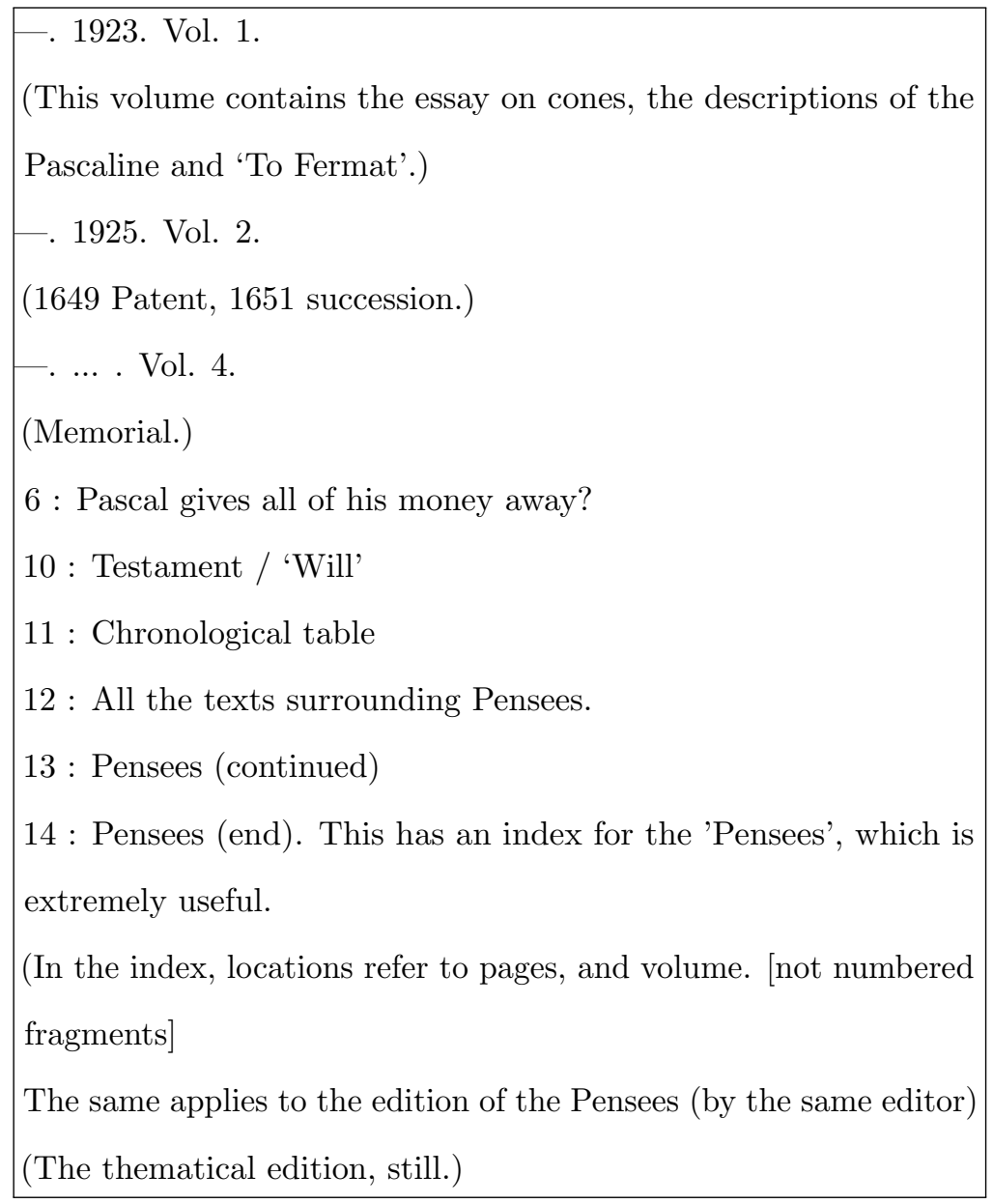

- Faugere (ed.). 1845. Lettres, opuscules et memoires... Vaton.

(452 ff. contains Marguerite's memoir; 353 ff. Jacqueline's 19/01/55 letter)

- (ed. unknown). 1858. Pensees de Pascal... Firmin Didot etc..

(One of many editions containing Gilberte's 'Life of Pascal'.)

- Giraud, Victor (int. and notes). 1922. Discours sur les Pensees... Bossard.

(Contains e.g. "Discours sur les Pensees" among others) 


\section{Bibliography}

- Aries, Philippe. 1962. Centuries of childhood. A social history of family life. Knopf.

- x-. 1975. Western attitudes toward death. From the Middle ages to the present. Marion Boyars.

- Bachelard, Gaston. ['The formation of the scientific mind'].

(Divisions in three periods, 'professorial mind' : preface; salon : ch. 2)

- Bauer, Friedrich. 2009. Historische Notizen zur Informatik. Springer.

(Computer scientist-turned-historian. Spiritual history. (Sociol. important.))

- ${ }^{\times}$Braudel, Fernand. 1985. Civilization and capitalism, 15th-18th century. Vol.

1 : The structures of everyday life. Collins sons and co..

- Bergin (ed.). 2001. The Seventeenth Century. Europe 1598-1795. Oxford University Press.

(This volume contains a chronology at the end, fashioned in the grand style of the history of kings and queens, and battles, and occasionaly only science...)

- Brockliss, Laurence. 2001. "The age of curiosity". In : Bergin.

- Chadwick, Henry. 2001. Augustine. A very short introduction. Oxford.

- Destouches, Louis-Ferdinand. 1999. Semmelweis. Gallimard. [Thesis in medicine]

- Dewald (ed. in chief). Europe 1450 to 1789. Encyclopedia of the Early Modern world. Many volumes. Cambridge.

(Vol. 1 : 'Arnauld Family', 'Atheism' ['Bourgeoisie', 'Census']... 2 : 'Death', etc..)

- Durkheim, Emil. 1884. Cours de philosophie... / 'Philosophy lessons given at Lycee de Sens'.

- Giraud, Victor. 1905. Pascal... ['The Man, The Works, The Influence']. Fontemoing. 
- Hazard, Paul. [1935]. La crise de la conscience europeenne. 1680-1715. Fayard. (If what Paul Hazard wrote of Pascal is true, namely that he had no disciples, then we must also contend that later centuries were full of them...)

- Irwin (ed.). 2002. The Matrix and Philosophy. Open Court.

- Lelut, Francisque. 1846. L'amulette de Pascal / 'Pascal's amulet'.

(Divided into two parts, the first of which has little if anything to do with Pascal being a psychologist's reflections on ideas' origins...)

- Michaut, Gustave. 1902. Les Epoques de la Pensee de Pascal. Fontemoing.

- Munck, Thomas. 2001. "Society". In : Bergin.

- Russell, Bertrand. A History of Western Philosophy.

(Ch. "Augustine", "Reformation", "Descartes", "Nietzsche"...)

- Strowski, Fortunat. 1907; 1908. Pascal et son temps. ['Pascal and his time']. Vol. 2 and 3. Plon.

- Taton, Rene. 1962. "Tableau chronologique sommaire de la vie et des travaux scientifiques de Pascal" Revue d'histoire des sciences 15(3-4) : 191-195.

•- - 1963. "Sur l'invention de la machine arithmétique" Revue d'histoire des sciences 16(2) : 139-160.

- Wiesner-Hanks, Merry. 2013. Early Modern Europe 1450-1789. Cambridge.

- Yeffeth (ed.). 2003. Taking the Red Pill: Science, Philosophy and Religion in The Matrix. Summersdale. 